\title{
Lizards and snakes of Refúgio de Vida Silvestre Matas do Siriji, an Atlantic Forest hotspot of the Pernambuco Endemism Center, Northeastern Brazil
}

\author{
José Henrique de Andrade Lima ${ }^{1,2,3}{ }^{(1)}$, Emerson Gonçalves Dias ${ }^{1,2,4}$, Rafael Dioni Leandro Costa \\ Flávio José Silva , Erica Suzan Martins Lima ${ }^{1,2,4}$, Ednilza Maranhão dos Santos ${ }^{4} \&$
}

Marcelo Nogueira de Carvalho Kokubum ${ }^{3,6,7}$

${ }^{1}$ Universidade Federal de Pernambuco, Departamento de Zoologia, Centro de Biociências, Programa de Pós Graduação em Biologia Animal, Av. Professor Moraes Rego, 1235, Cidade Universitária, 50670-901, Recife, PE, Brasil.

${ }^{2}$ Universidade Federal de Pernambuco, Departamento de Zoologia, Centro de Biociências, Laboratório de Herpetologia, Av. Professor Moraes Rego, 1235, Cidade Universitária, 50670-901, Recife, PE, Brasil.

${ }^{3}$ Universidade Federal de Campina Grande, Centro de Saúde e Tecnologia Rural, Unidade Acadêmica de Ciências Biológicas, Laboratório de Herpetologia, Av. dos Universitários, Santa Cecília, 58700-970, Patos, $P B$, Brasil.

${ }^{4}$ Universidade Federal Rural de Pernambuco, Departamento de Biologia, Laboratório Interdisciplinar de Anfibios e Répteis, Rua Manoel de Medeiros, Dois Irmãos, 52171-900, Recife, PE, Brasil.

${ }^{5}$ Universidade Federal da Paraíba, Centro de Ciências Agrárias, Programa de Pós-graduação em Biodiversidade, Campus II, Rodovia BR 079-Km 12, 58397-000, Areia, PB, Brasil.

${ }^{6}$ Universidade Federal de Campina Grande, Centro de Saúde e Tecnologia Rural, Programa de Pós-graduação em Ciências Florestais, Av. dos Universitários, Santa Cecília, 58700-970, Patos, PB, Brasil.

${ }^{7}$ Universidade Estadual da Paraíba, Programa de Pós-graduação em Ecologia e Conservação, Rua Baraúnas, 351, Complexo Três Marias, 58429-500, Campina Grande, PB, Brasil. *Corresponding author: José Henrique de Andrade_Lima, e-mail: henrique_bio@outlook.com

ANDRADE LIMA, J.H., DIAS, E.G., COSTA, R.D.L., SILVA, F.J., LIMA, E.S.M., SANTOS, E.M., KOKUBUM, M.N.C. Lizards and snakes of Refúgio de Vida Silvestre Matas do Siriji, an Atlantic Forest hotspot of the Pernambuco Endemism Center, Northeastern Brazil. Biota Neotropica 21(2): e20201106.

https://doi.org/10.1590/1676-0611-BN-2020-1106

\begin{abstract}
The Atlantic Forest north of the São Francisco River, known as the Pernambuco Endemism Center (PEC), comprises small, poorly-known and, consequently, highly threatened forest remnants, such as Refúgio de Vida Silvestre (RVS) Matas do Siriji, a montane forest located in the municipality of São Vicente Férrer, state of Pernambuco, Northeast Brazil. We provide the results of the first inventory of the squamate fauna of the region with comments on the conservation status of some species, comparisons with other locations in Northeast Brazil and a brief discussion of biogeography. Time-constrained transects, pit-fall traps, occasional encounters and third-party records registered 18 lizard species and 25 snake species, with the rarefaction curve of the former tending to stability. The RVS Matas do Siriji possesses $39.81 \%$ of the lizard and snake species known for the state of de Pernambuco, being the third richest area in species in the State, with a composition similar to that of other areas within PEC. Based on the lists of SEMAS, ICMBio and IUCN, some of the registered species are considered vulnerable to extinction while others have yet to be evaluated. The RVS Matas do Siriji includes a rich, threatened and underestimated fauna of squamate reptiles, indicating that more restrictive protection measures must be adopted in this Conservation Unit.

Keywords: Northeastern Atlantic Forest; state of Pernambuco; Squamata; Endangered species.
\end{abstract}

\section{Lagartos e serpentes do Refúgio de Vida Silvestre Matas do Siriji, um hotspot da Mata Atlântica do Centro de Endemismo Pernambuco, Nordeste do Brasil}

Resumo: A Mata Atlântica ao norte do Rio São Francisco, conhecida como Centro de Endemismo Pernambuco (CEP), é composta pelos menores, menos conhecidos e, consequentemente, mais ameaçados remanescentes florestais, como o Refúgio de Vida Silvestre (RVS) Matas do Siriji, uma floresta serrana localizada no município 
de São Vicente Férrer, Pernambuco, Nordeste do Brasil. Aqui apresentamos o primeiro inventário sobre a fauna de Squamata dessa região, com comentários sobre o status de conservação de algumas espécies, similaridade na composição com outras localidades do Nordeste do Brasil e uma breve discussão biogeográfica. Foram utilizados transectos limitados por tempo, armadilhas de queda, encontros ocasionais e registro por terceiros. Registramos 18 espécies de lagartos e 25 de serpentes com a curva de rarefação de lagartos próxima da estabilidade. O RVS Matas do Siriji possui 39,81 \% das espécies de lagartos e serpentes do Estado de Pernambuco, ocupando o terceiro lugar em número de espécies no Estado e apresentando uma composição similar a de outras áreas do CEP. Além disso, com base nas listas da SEMAS, ICMBio e IUCN, algumas das espécies registradas encontram-se em estado vulnerável a extinção e outras não possuem avaliação. Portanto, o RVS Matas do Siriji comporta uma rica, ameaçada e subestimada fauna de répteis Squamata e medidas de proteção mais restritivas devem ser adotadas nessa Unidade de Conservação.

Palavras-chave: Mata Atlântica nordestina; Estado de Pernambuco; Squamata; Espécies ameaçadas.

\section{Introduction}

Centuries of successive economic cycles and constant occupation of Atlantic Forest environments has seriously compromised the ecological balance of the unique ecosystems of the domain (Silva \& Casteleti 2005). The Atlantic Forest originally covered an area of 1,480,000 $\mathrm{km}^{2}$, which corresponds to $17 \%$ of the national territory (Freitas et al. 2019). Today, only $160,000 \mathrm{~km}^{2}(12.4 \%)$ of the coverage of the Atlantic Forest domain remains (SOS Mata Atlântica \& INPE 2019), which houses at least $1 \%$ to $8 \%$ of the world's biodiversity (Silva \& Casteleti 2005), earning it recognition as a global biodiversity hotspot (Myers et al. 2000).

Northeast Brazil has the lowest coverage of remaining of Atlantic Forest and the lowest amount of protected areas (Lobo-Araújo et al. 2013, Vale et al. 2018), even though it has great biological importance due to high endemism, especially north of the São Francisco River. Among the biogeographic subunits that make up the Northeastern Atlantic Forest is the Pernambuco Endemism Center (PEC) (Rizzini 1997, Cavalcanti \& Tabarelli 2004), a region that extends from the state of Alagoas to the state of Rio Grande do Norte (Prance 1982, Santos et al. 2007). The region possesses high endemism, with emphasis on plants (Prance 1982, Santos et al. 2007), butterflies (Brown 1979, Tyler et al. 1994) and birds (Silva et al. 2004, Lobo-Araújo et al. 2013, Vale et al. 2018), and is considered to have been an important refuge for Atlantic Forest species north of the São Francisco River during Quaternary climate changes (see Carnaval et al. 2009, Porto et al. 2013, Costa et al. 2017).

Thus far, a total of 84 lizard species (Tozetti et al. 2017) and 142 snakes species (Marques et al. 2019) have been documented for the Atlantic Forest and although such estimates have yet to be made for PEC, some works have already contributed to the knowledge of its reptile fauna (Silva et al, 2006, Santana et al. 2008, Moura et al. 2012, Moura et al. 2015, Roberto et al. 2015, Oliveira et al. 2016, Roberto et al. 2017, Melo et al. 2018, Mesquita et al. 2018). Nonetheless, the herpetofauna of many areas remains to be sampled and evaluated, especially with regard to conservation (Roberto et al. 2017). Thus, it is extremely necessary and urgent that the herpetofauna of remnants that make up the PEC be surveyed, as the results of such studies are essential to better target conservation action plans (Margules \& Pressey 2000). At least 15 species of squamate reptiles present in PEC were contemplated by the Plano Nacional para Conservação da Herpetofauna Ameaçada da Mata Atlântica Nordestina (PAN) (ICMBio 2019), four Endangered (EN): Coleodactylus natalensis, Leposoma baturitensis, Atractus caete and Bothrops muriciensis; two Vulnerable (VU): Echinanthera cephalomaculata and Amerotyphlops paucisquamus; four Near
Threatened (NT): Amphisbaena carvalhoi, A. heathi, A. lumbricalis and Coleodactylus elizae; and five Data Deficient (DD): Ophiodes striatus, Atractus maculatus, A. potschi, Dendrophidion atlantica and Liotyphlops trefauti.

The purpose of the present study was to inventory the species that comprise the squamate taxocenosis of Refúgio de Vida Silvestre (RVS) Matas do Siriji, a forest of PEC, and to characterize the taxocenosis, discuss the conservation status of its species and compare its squamate composition with that of other areas of Northeast Brazil.

\section{Material and Methods}

\section{Study area}

The RVS Matas do Siriji (Figure 1) ( $\left.7^{\circ} 37^{\prime} \mathrm{S}, 35^{\circ} 30^{\prime} \mathrm{W}\right)$, also known as Mata do Siriji or Mata do Estado, is located between 600 and $640 \mathrm{~m}$ in altitude in the municipality of São Vicente Férrer, state of Pernambuco (Ferraz \& Rodal 2006), Northeast Brazil. The climate is hot and humid according to the Köppen classification, with a dry summer and a rainy season that starts in January/February and ends in September but can extend until October (Beltrão et al. 2005). The RVS encompasses $600 \mathrm{ha}\left(6.3 \mathrm{Km}^{2}\right)$ (Figure 1B) of montane forest (Rodal et al. 1998) composed of Dense and Montane Ombrophilous Forest (Figure 1C) (Pietrobom \& Barros 2002).

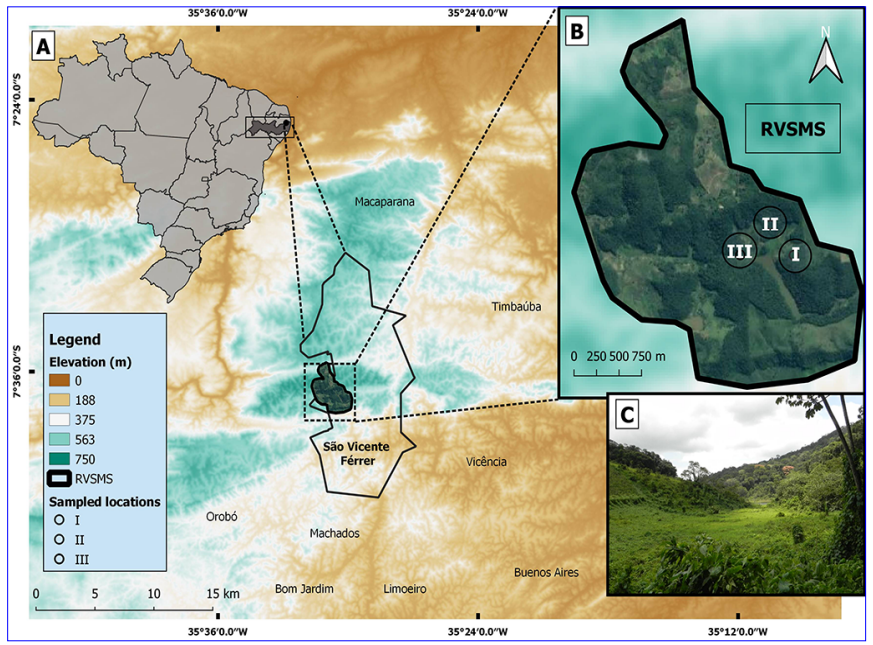

Figure 1. Location of the study area - Refúgio de Vida Silvestre Matas do Siriji, in the state of Pernambuco (A; dark grey), municipality of São Vicente Férrer (B), Northeastern Brazil. The numbered circles (I, II and III) represent the sampled subareas. (C) Landscape of an environment found in the area. 
Three subareas were selected for sampling (Figure 1B) and assessed for their structure and environmental conditions:

— Subarea I $\left(07^{\circ} 37^{\prime} 00.4^{\prime \prime S}, 035^{\circ} 30^{\prime} 17.3^{\prime \prime} \mathrm{W}, 575 \mathrm{~m}\right)$. With a history of growing manioc 50 years ago, and its subsequent abandonment, Subarea I currently possesses a shrub-tree stratum with little open space and is marked by a large number of young A. Banana (Musa spp.) monoculture surrounds the subarea almost completely and human presence is more frequent in this subarea than in the others. The terrain has little declivity $(8.2 \%)$ and is considered undulating. It has, on average: $74 \%$ canopy coverage; $6.03 \mathrm{~cm}$ litter height; five trees per every $16 \mathrm{~m}^{2}$ of $15 \mathrm{~m}$ in height and $31.20 \mathrm{~cm}$ circumference at breast height (CBH); air and soil temperature of $22.5^{\circ} \mathrm{C}$ and $24^{\circ} \mathrm{C}$, and air and soil humidity of $81 \%$ and $85 \%$, respectively.

— Subarea II (07³6'49.9’'S, 035³0’25.9’W, 566 m). Marked by great declivity $(40.1 \%)$, this subarea area was classified as strongly undulating. It is composed of a predominantly arboreal stratum that is slightly more spaced than in subareas I and III. No livestock or agriculture areas have been developed in the subarea but there are some trails. There is a source of water and an artificial pond at the beginning of the path of this subarea, while at the halfway mark there is a marked presence of rocks of varying sizes and many jackfruit (Artocarpus heterophyllus) from seedlings to large individuals of $15 \mathrm{~m}$. The subarea has, on average: $80 \%$ canopy cover; $5.92 \mathrm{~cm}$ litter height; four trees per every $16 \mathrm{~m}^{2}$ of $14 \mathrm{~m}$ in height and $27.98 \mathrm{~cm} \mathrm{CBH}$; air and soil temperature both $25.5^{\circ} \mathrm{C}$; air and soil humidity of $78 \%$ and $83 \%$, respectively.

— Subarea III $\left(07^{\circ} 36^{\prime} 58.0^{\prime \prime} \mathrm{S}, 035^{\circ} 30^{\prime} 37.1^{\prime \prime} \mathrm{W}, 537 \mathrm{~m}\right)$. This subarea is more heterogeneous because it is markedly arboreal, including the presence of trees with tabular roots. It has a part with "bare" soil and a $20 \mathrm{~m}^{2}$ rocky outcrop while the end of the path has a dense forest in better condition of preservation with natural streams, presenting gently undulating declivity (7.4\%). This subarea has, on average: $85 \%$ canopy coverage; $6.24 \mathrm{~cm}$ litter height; four trees per every $16 \mathrm{~m}^{2}$ of $15 \mathrm{~m}$ in height and $34.61 \mathrm{~cm} \mathrm{CBH}$; air and soil temperature of $24.5^{\circ} \mathrm{C}$ and $23.7^{\circ} \mathrm{C}$; and air and soil humidity of $79 \%$ and $82 \%$, respectively.

\section{Sampling}

Data collection was performed monthly from April 2018 to September 2019 (with the exception of May, June, August and September 2018), during field expeditions of seven or eight consecutive days (total of 102 days in the field).

Time-constrained visual searches of $1 \mathrm{hr} 30 \mathrm{~min}$ were performed systematically along transects in each subarea (Crump \& Scott Jr. 1994) by five observers each period (morning, afternoon and night) of the day for a total of 2,205 hours (1,530 during the day / 675 at night; 441 hours/ observer). Pitfall traps (Cechin \& Martins 2000) were also used with two linear arrays, separated by at least $50 \mathrm{~m}$, of five buckets each - a 601 bucket at each end and three 201 buckets in between, all separated by $5 \mathrm{~m}$ - per subarea for a total of 864 hours/bucket. Were also included occasional encounters and third-party records, which consists of photos provided during the study by people who live in the area.

Collected specimens (Appendix) were identified using Freitas (2015), Roberto et al. (2017) and consultation with experts. Still in the field were fixed, and finally deposited in the collection of the Laboratório de Herpetologia da Universidade Federal de Campina Grande (LHUFCG), in the municipality of Patos, state of Paraíba, Brazil and in the Coleção Paleoherpetológica e Herpetológica da Universidade Federal Rural de Pernambuco (CPH-UFRPE) and in the Coleção de Zoologia Didática da Universidade Federal Rural de Pernambuco (CZDUFRPE), in the municipality of Recife, state of Pernambuco, Brazil. All procedures were carried out under permanent licenses for the collection of zoological material (SISBIO number. 11218-1 and 66285-1), as well as authorization from Secretaria de Meio Ambiente e Sustentabilidade (CPRH) management (process number 014349/2018).

\section{Data analysis}

In describing the taxocenosis, the number of sightings of a species was considered equivalent to its abundance since abundance itself was not assessed. Dominance (d) (Berger-Parker index), equitability (J) (Pielou index) and diversity of the taxocenosis were obtained through the Shannon-Wiener index $\left(\mathrm{H}^{\prime}\right)$ (Magurran 1988) using PAST 3.25 software (Hammer et al. 2001). An abundance distribution diagram was created and tested using relative frequency [(number of samples with a record of a species/total number of samples) $x$ 100] and relative abundance [(number of individuals of the same species/total number of individuals collected in the area) $x$ 100] of each species (Dajoz 2005), based on the adequacy of theoretical models of distribution and abundance (broken-stick, geometric, log-series or log-normal) (Melo 2008, Mesquita et al. 2013).

Values for the species rarefaction curves were obtained with PAST 3.25 (Hammer et al. 2001) using the rarefaction system with 10,000 randomizations (using sampling days as sample units). The values were then transferred to Microsoft Excel (2016), where graphs more representative of the curves' behavior were produced to evaluate the efficiency of the sampling effort (Gotelli \& Colwell 2001). Species richness for lizards and snakes were estimated using the non-parametric estimators ICE and Jacknife II (Colwell \& Coddington 1994) in Estimates 9.1.0 software (Colwell \& Elsensohn 2014).

Classical cluster analyses were performed for lizards (79 spp.) and snakes (122 spp.) separately using the Jaccard Index (presence (1) / absence (0)) (Magurran 2004) in PAST 3.25 (Hammer et al. 2001). Records of squamate species at 36 locations in the Northeastern Atlantic Forest and associated ecosystems, including RVS Matas do Siriji, were used: 19 montane forests, including forest enclaves in the semiarid region - Serra do Urubu (Moura et al. 2011, Roberto et al. 2017), municipalities of Arcoverde, Belo Jardim and Sertânia (Freitas et al. 2019a), in Pernambuco state; Agrestina, Arara, Bananeiras, Bezerros, Brejo dos Cavalos, Brejo de Madre de Deus and Mata do Pau-Ferro (Pereira-Filho \& Montingelli 2011; Pereira-Filho et al. 2020), in Pernambuco and Paraíba states; Reserva Biológica Pedra Talhada (Roberto et al. 2015), Pernambuco state; Chapada do Araripe (Borges-Nojosa \& Caramaschi 2003, Ribeiro et al. 2008, Ribeiro et al. 2012), Ceará state; Parque Estadual Pico do Jabre (Pereira-Filho \& Montingelli 2011, Arruda 2017), Paraíba state; and Planalto do Ibiapaba (including Parque Nacional do Ubajara) and (Borges-Nojosa \& Caramaschi 2003, Loebmann \& Haddad 2010, Castro et al. 2019) Serra do Maranguape, Serra da Aratanha and Maciço do Baturité (BorgesNojosa \& Caramaschi 2003, Borges-Nojosa 2007), Ceará state; 14 low altitude fragments of Atlantic Forest near the coast - Estação Ecológica do Tapacurá (Moura et al. 2012), rainforest fragment Tejipió (Oliveira et al. 2016) and Parque Estadual Dois Irmãos (Santos et al. 2017, Melo et al. 2018), Pernambuco state, Área de Preservação Permanente Mata 
do Buraquinho (Santana et al. 2008) and Reserva Biológica Guaribas (Mesquita et al. 2018), Paraíba state, Reserva Madeiras (Moura et al. 2015), Reserva Particular Usina Porto Rico (Queissada 2009) and Mata do Engenho Coimbra, Alagoas state (Gonçalves 2008), Refúgio de Vida Silvestre Matas do Junco (Morato et al. 2011), Sergipe state, Área de Proteção Ambiental Lagoa Encantada (Dias et al. 2014), of northeastern coast the Bahia (Marques et al. 2017), Recôncavo Baiano (Freitas 2014), Serra da Jiboia (Freitas et al. 2018) and Serra do Timbó (Freitas et al. 2019b), Bahia state; and three areas of mesic caatinga Parque Nacional Chapada Diamantina (Magalhães et al. 2015), Bahia state, Parque Nacional Serra das Confusões (Vechio et al. 2016) and Parque Nacional Serra da Capivara (Cavalcanti et al. 2014), Piauí state. The aim was to assess similarities among these areas and determine if they form groups based on the three types of formations, and if so, to which does RVS Matas do Siriji belong.

Dendrograms were produced for lizards and snakes with, respectively, 28 (12 montane forests, 13 low-altitude Atlantic Forest fragments and three areas of mesic caatinga) and 31 (15 mountain forests, 13 low-altitude Atlantic Forest fragments and three areas of mesic caatinga) localities because only lizards (four locations) or snakes (eight locations) were inventoried at some locations.

Species registered only through third-party records were included only in the species list and in the classical cluster analysis.

\section{Species conservation status}

Conservation status was assessed using the list published by Secretaria de Meio Ambiente e Sustentabilidade (SEMAS 2017) of the state of Pernambuco, Livro Vermelho da Fauna Brasileira Ameaçada de Extinção (ICMBio 2018) and the Red List of Threatened Species of the International Union for the Conservation of Nature (IUCN 2020). Only Hemidactylus mabouia was not evaluated since it is exotic. Taxonomic nomenclature follows Costa and Bérnils (2018).

\section{Results}

A total of 43 species were recorded during the study period, of which 18 were lizards belonging to 10 families and 25 were snakes belonging to six families (Table 1; Figures 2-7). Most species were recorded through occasional encounters $(n=26), 16$ of which $(37.21 \%$ of all species) were exclusively detected by this method (Table 1 ). Timeconstrained visual searches recorded the second most species $(n=24), 12$ of which $(27.91 \%)$ were only recorded by this method (Table 1$)$. Pitfall traps collected seven individuals of four species, two of which (4.65\%) were recorded exclusively by this method - the lizard Dryadosaura nordestina and the snake Amerotyphlops arenensis. Third-party records added two species (4.65\%), which were both snakes (Table 1). Another species (Oxyrhopus petolarius digitalis) was registered in the area by third parties after the end of the study, and was added to the list.

The rarefaction curve for lizards approached the asymptote and ICE and Jacknife II estimators predicted $18.7( \pm 0)$ and $20( \pm 0)$ species, respectively (Figure $8 \mathrm{~A}$ ). Thus, these estimators predicted between one and two more species than were recorded by our sampling effort (18). The rarefaction curve for snakes did not cease increasing and ICE and Jacknife II estimators predicted $41.49( \pm 0)$ and $41.76( \pm 0)$ species (Figure $8 \mathrm{~B}$ ), both of which are 20 more species than were recorded by our sampling effort (22).
Among the lizards, Enyalius aff. catenatus and Gymnodactylus darwinii were the most frequently seen, representing $17 \%(\mathrm{n}=41)$ and $12 \%(n=28)$ of the total number of sightings $(n=239)$ of the entire taxocenosis. Among snakes, Dipsas variegata and Lachesis muta were most recorded, representing $4 \%(n=10)$ and $3 \%(n=8)$ of the total number of sightings of the whole taxocenosis (Table 1).

The reptile taxocenosis showed low dominance $(\mathrm{d}=0.139)$ and high equitability $(\mathrm{J}=0.824)$, indicating that it is stable $\left(\mathrm{H}^{\prime}=3.080\right)$. It fit the log-normal model (Figure 9), as there was no significant difference between the distribution of abundances of the taxocenosis and the model $\left(\mathrm{X}^{2}=2.907 ; p=0.234\right)$.

Among the species found in RVS Matas do Siriji, three had a conservation status of Vulnerable (Strobilurus torquatus, Dipsas sazimai and Lachesis muta), according to at least one of the three lists consulted (Table 1). Dendrophidion atlantica is considered Data Deficient (DD) by ICMBio (2018) and was not evaluated by the other lists (SEMAS 2017 and IUCN 2020), whereas only Amerotyphlops arenensis was not evaluated by any of the lists (Table 1).

The similarity dendrogram for lizards (Figure 10A) formed two large groups, represented by different phytophysiognomies, with Group I (upper part) comprising 12 areas with a predominance of mesic caatinga with small remnants of seasonal Atlantic Forest; and Group II (bottom part) comprising 15 areas of Atlantic Forest, with montane or lowland, dense or open ombrophilous forest. In this dendrogram, RVS Matas do Siriji is inserted in Group II, sharing greater composition (59\%) with Parque Estadual de Dois Irmãos (PEDI-PE), although also sharing just over 50\% with Área de Proteção Permanente Mata do Buraquinho (APPMB-PB), Reserva Particular Usina Porto Rico (RPUPR-AL), Reserva Madeiras (RM-AL) and Mata do Engenho Coimbra (MEC-AL).

The similarity dendrogram for snakes (Figure 10B) revealed that RVS Matas do Siriji shared a maximum of $40 \%$ of its composition with Serra do Urubu (SU-PE) and 30\% with other areas with montane or plain, dense or open ombrophilous forest. Groupings with considerable similarity with RVS Matas do Siriji and other areas were not observed. A grouping of montane forests located more centrally and northwest of the Caatinga, including Parque Estadual Pico do Jabre (PEPJ-PB), Arcoverde (AV-PE), Sertânia (SE-PE), Belo Jardim (BJ-PE) and Chapada do Araripe (CA-CE), remained in both dendrograms, sharing $34 \%$ of their compositions in the snake dendrogram and $54 \%$ in the lizard dendrogram (Figure 10).

\section{Discussion}

To date, there is an estimated 41 species of lizards and 67 species of snakes in the state of Pernambuco (SEMAS 2017). Thus, RVS Matas do Siriji possesses $39.81 \%$ of the lizard and snake species of the state, with more species than RPPN Pedra D'antas and RPPN Frei Caneca (which make up Serra do Urubu) with 37.04\% (Roberto et al. 2017), and fewer than Estação Ecológica do Tapacurá (47.22\%) (Moura et al. 2012) and Parque Estadual de Dois Irmãos (48.15\%) (Santos et al. 2017, Melo et al. 2018), all of which are areas of extreme importance for the state of Pernambuco and for PEC as a whole.

Most species had a similar number of sightings, and thus the taxocenose had high equitability and low dominance and did not differ significantly from the log-normal model (Figure 9). According to Dajoz (2005), a fit to this model is common for communities controlled by 
Table 1. List of lizard and snake species recorded in Refúgio de Vida Silvestre Matas do Siriji, municipality of São Vicente Férrer, state of Pernambuco, Northeastern Brazil, between April 2018 and September 2019, with respective collection methods, relative frequency, conservation status (according SEMAS, ICMBio and IUCN) and record type. TCVS = time-constrained visual search, OE $=$ occasional encounter, PT= pitfall trap, $\mathrm{TPR}=$ third-party records, $\mathrm{TPR} *=$ third-party records after study, $\mathrm{LC}=$ Least Concern, $\mathrm{DD}=\mathrm{Data}$ Deficient, $\mathrm{VU}=\mathrm{Vulnerable}, \mathrm{AF}=$ restricted to the Atlantic Forest, $\mathrm{PEC}=$ restricted to the Atlantic Forest and endemic to PEC.

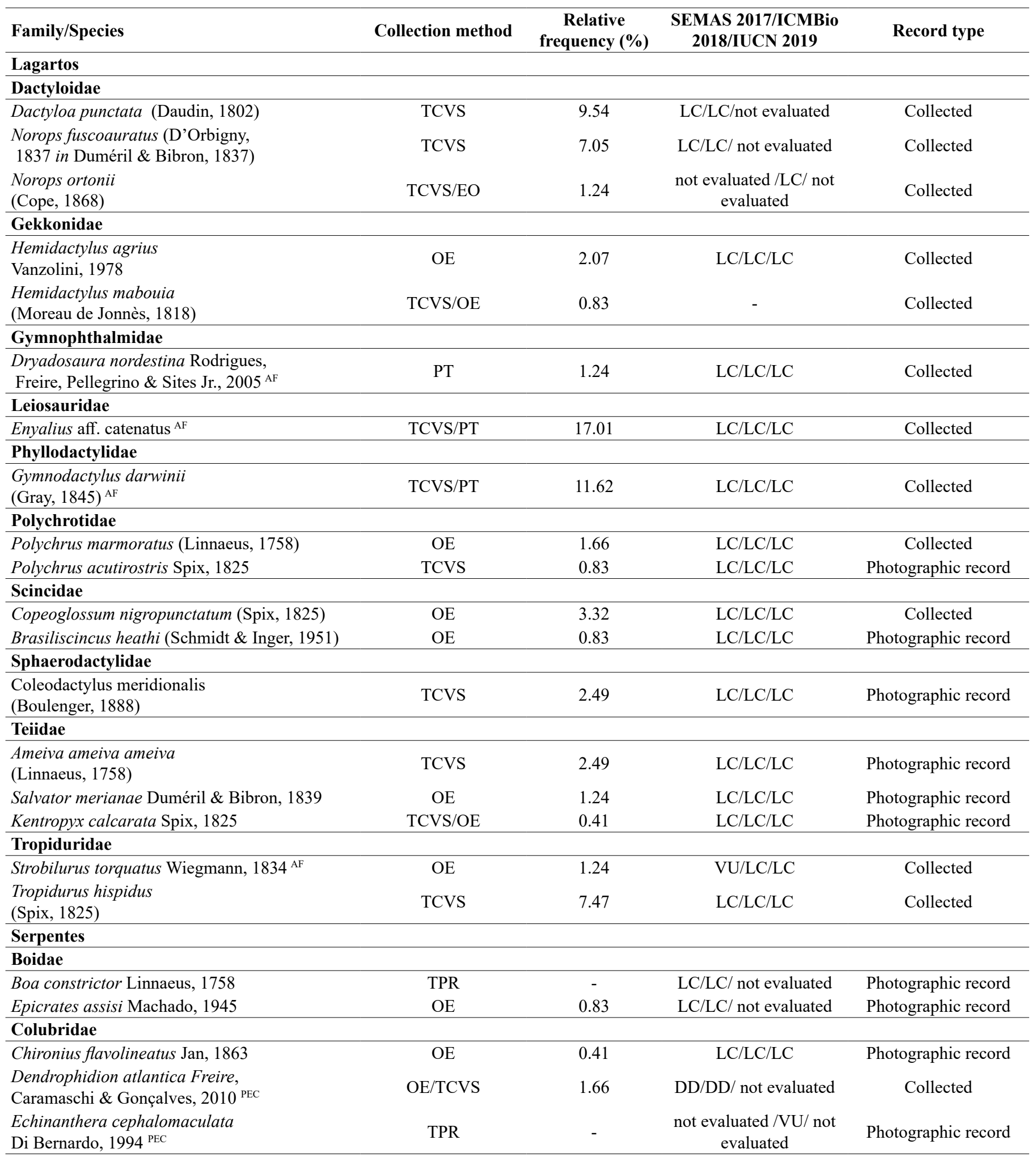


Continuation..

\begin{tabular}{|c|c|c|c|c|}
\hline $\begin{array}{l}\text { Echinanthera cephalostriata } \\
\text { Di Bernardo, } 1996^{\mathrm{AF}}\end{array}$ & TCVS & 1.24 & not evaluated /LC/LC & Collected \\
\hline Oxybelis aeneus (Wagler in Spix, 1824) & $\mathrm{OE}$ & 0.83 & $\mathrm{LC} / \mathrm{LC} / \mathrm{LC}$ & Collected \\
\hline Spilotes pullatus pullatus (Linnaeus, 1758) & TCVS & 0.41 & $\mathrm{LC} / \mathrm{LC} / \mathrm{LC}$ & Collected \\
\hline Tantilla melanocephala (Linnaeus, 1758) & $\mathrm{OE}$ & 0.41 & $\mathrm{LC} / \mathrm{LC} / \mathrm{LC}$ & Collected \\
\hline \multicolumn{5}{|l|}{ Dipsadidae } \\
\hline $\begin{array}{l}\text { Dipsas variegata } \\
\text { (Duméril, Bibron \& Duméril, 1854) }\end{array}$ & OE/TCVS & 4.15 & $\mathrm{LC} / \mathrm{LC} / \mathrm{LC}$ & Collected \\
\hline $\begin{array}{l}\text { Dipsas sazimai Fernandes, } \\
\text { Marques \& Argôlo, } 2010^{\mathrm{AF}}\end{array}$ & $\mathrm{OE}$ & 0.41 & $\mathrm{VU} / \mathrm{LC} / \mathrm{LC}$ & Collected \\
\hline Erythrolamprus taeniogaster (Jan, 1863) & OE/TCVS & 0.83 & $\mathrm{LC} / \mathrm{LC} / \mathrm{LC}$ & Collected \\
\hline $\begin{array}{l}\text { Philodryas nattereri } \\
\text { Steindachner, } 1870\end{array}$ & $\mathrm{OE}$ & 0.41 & $\mathrm{LC} / \mathrm{LC} / \mathrm{LC}$ & $\begin{array}{l}\text { Photographic } \\
\text { record }\end{array}$ \\
\hline $\begin{array}{l}\text { Philodryas olfersii } \\
\text { (Lichtenstein, 1823) }\end{array}$ & $\mathrm{OE}$ & 0.41 & $\mathrm{LC} / \mathrm{LC} / \mathrm{LC}$ & $\begin{array}{l}\text { Photographic } \\
\text { record }\end{array}$ \\
\hline Imantodes cenchoa (Linnaeus, 1758) & TCVS/OE & 2.49 & $\mathrm{LC} / \mathrm{LC} / \mathrm{LC}$ & Collected \\
\hline Oxyrhopus guibei Hoge \& Romano, 1978 & OE & 1 & $\mathrm{LC} / \mathrm{LC} / \mathrm{LC}$ & Collected \\
\hline $\begin{array}{l}\text { Oxyrhopus petolarius digitalis ( } \\
\text { Reuss, 1834) }\end{array}$ & TPR* & - & $\mathrm{LC} / \mathrm{LC} / \mathrm{LC}$ & $\begin{array}{l}\text { Photographic } \\
\text { record }\end{array}$ \\
\hline $\begin{array}{l}\text { Oxyrhopus trigeminus } \\
\text { Duméril, Bibron \& Duméril, } 1854\end{array}$ & $\mathrm{OE}$ & 0.83 & $\mathrm{LC} / \mathrm{LC} / \mathrm{LC}$ & Collected \\
\hline $\begin{array}{l}\text { Pseudoboa nigra } \\
\text { (Duméril, Bibron \& Duméril, 1854) }\end{array}$ & TCVS & 0.83 & $\mathrm{LC} / \mathrm{LC} / \mathrm{LC}$ & $\begin{array}{c}\text { Photographic } \\
\text { record }\end{array}$ \\
\hline Taeniophallus affinis (Günther, 1858) ${ }^{\mathrm{AF}}$ & $\mathrm{OE}$ & 1 & not evaluated /LC/LC & Collected \\
\hline $\begin{array}{l}\text { Xenodon rabdocephalus rabdocephalus } \\
\text { (Wied-Neuwied, 1824) }\end{array}$ & OE/TCVS & 1.66 & $\begin{array}{l}\text { not evaluated } / \mathrm{LC} / \text { not } \\
\text { evaluated }\end{array}$ & Collected \\
\hline \multicolumn{5}{|l|}{ Elapidae } \\
\hline $\begin{array}{l}\text { Micrurus lemniscatus carvalhoi } \\
\text { Roze, } 1967\end{array}$ & $\mathrm{OE}$ & 1 & $\mathrm{DD} / \mathrm{LC} / \mathrm{LC}$ & $\begin{array}{c}\text { Photographic } \\
\text { record }\end{array}$ \\
\hline \multicolumn{5}{|l|}{ Typhlopidae } \\
\hline $\begin{array}{l}\text { Amerotyphlops arenensis Graboski, Pereira- } \\
\text { Filho, Silva, Prudente \& Zaher, } 2015^{\text {PEC }}\end{array}$ & PT & 1.24 & $\begin{array}{l}\text { not evaluated / not evaluated / } \\
\text { not evaluated }\end{array}$ & Collected \\
\hline \multicolumn{5}{|l|}{ Viperidae } \\
\hline Bothrops leucurus Wagler in Spix, $1824^{\mathrm{AF}}$ & OE/TCVS & 2.49 & $\mathrm{LC} / \mathrm{LC} /$ not evaluated & Collected \\
\hline Lachesis muta (Linnaeus, 1766) & TCVS & 3.32 & $\mathrm{VU} / \mathrm{LC} / \mathrm{VU}$ & Collected \\
\hline
\end{tabular}

several ecological factors, which leads to a balance in the sharing of available resources or, in other words, less competition, which is a commonly observed pattern for tropical forests.

The richness estimators ICE and Jacknife II indicated that, in 102 days of sampling, we recorded between $90 \%$ and $96 \%$ of the maximum expected lizard richness and $53 \%$ of the maximum expected snake richness (without considering the three snake species obtained by third-party records). Curves that do not reach an asymptote (Figure 8) demonstrate a need for continued sampling (Gotelli \& Colwell 2001), which is reinforced by the species recorded by the third-party records during and after the study. In addition, species richness is proportional to sampling effort (Melo et al. 2003), and so it would take a greater sampling effort to record the rest of the species, especially the snakes. Thus, the present list of species is an initial milestone in the study of reptiles of RVS Matas do Siriji.

The methods that contributed the most to determining richness and abundance in the present study were, respectively, occasional encounters and time-constrained visual searches (Table 1). The efficiency of these methods for registering reptiles has been reported in many studies in different biomes (Carvalho et al. 2005, Freitas \& Silva 2007, Quintela et al. 2010, Roberto et al. 2017), including Pedrosa et al. (2014) who reported that such methods are better for sampling snakes. On the other hand, pitfall traps represented a less efficient method, especially for snakes. According to Cechin \& Martins (2000), pitfall traps are less efficient in environments with high vertical structure, that is, forest environments in which many species have an arboreal habit. However, the importance of this method (How \& Shine 1999, Henderson et al. 2016) in recording fossorial species, such as Amerotyphlops arenensis and Dryadosaura nordestina (Roberto et al. 2017), and especially lizards and snakes with active foraging, is undeniable.

The third-party records are also of paramount importance, as has been seen in the literature for snake inventories, due to its fortuitous character (Cunha \& Nascimento 1978, Cechin \& Martins 2000). Indeed, the voluntary contribution of residents of RVS Matas do Siriji to the present study led to the inclusion of three additional species of snakes (Boa constrictor, Echinanthera cephalomaculata and Oxyrhopus petolarius digitalis), one of which is considered VU according to ICMBio. These findings confirm the efficiency of using a combination of different methods to optimize the sampling of snakes (Caldas et al. 2016).

Although most of the species observed in the present study are considered Least Concern (LC) by SEMAS (2017) (27 species), ICMBio 

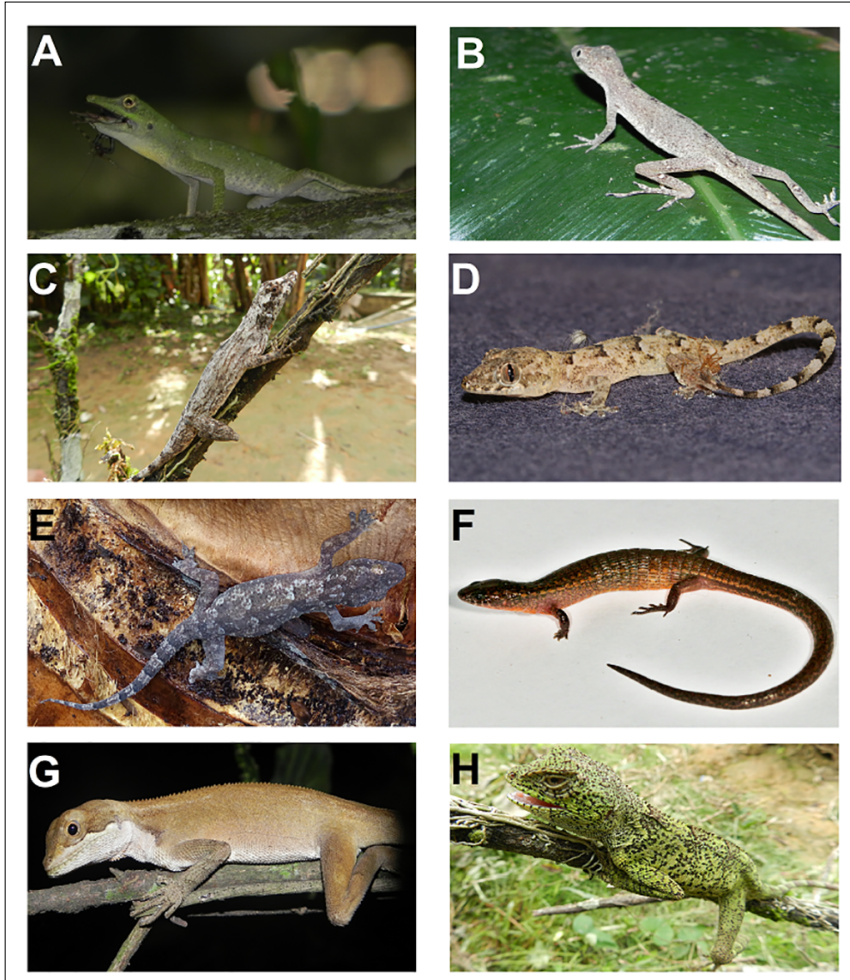

Figure 2.Lizard species registered in Refúgio de Vida Silvestre Matas do Siriji, municipality of São Vicente Férrer, state of Pernambuco, Northeastern Brazil, between April 2018 and September 2019. (A) Dactyloa punctata (LHUFCG 2224), (B) Norops fuscoauratus (unvouchered, juvenile),(C) Norops ortonii (CPH-UFRPE 5461),(D) Hemidactylus agrius (unvouchered, juvenile), (E) Hemidactylus mabouia (unvouchered), (F) Dryadosaura nordestina (LHUFCG 2316), (G) Enyalius aff. catenatus (unvouchered, female) (H) Enyalius aff. catenatus (CPH-UFRPE 5479, male).

(2018) (34 species) and IUCN (2020) (26 species), some considerations are needed with regard to species in the VU and DD categories, as well as the lack of evaluation for some species (Table 1):

The snake Echinanthera cephalomaculata is an endemic species of PEC, with its first record being at its type locality in the state Alagoas (Di-Bernardo 1994, Roberto et al. 2015) and recent records for three locations in the state of Pernambuco (Freitas et al. 2019b). Its registration in RVS Matas do Siriji, therefore, expands its distribution $74 \mathrm{~km}$ to the north of its nearest record (municipality of Gravatá, state of Pernambuco). Since the expansion of its distribution to the state of Pernambuco was done after the publication of the SEMAS list, the absence of its ranking is justifiable; nonetheless it is in urgent need of evaluation, such as by IUCN. The other species of the genus, $E$. cephalostriata, also recently had its distribution expanded in the state of Pernambuco (Dias et al. 2019), which was also its second record for PEC - the first record was done by Roberto et al. (2015), and was also not evaluated by SEMAS.

The snake species Taeniophallus affinis is also not listed by SEMAS due to the fact that its two records in the state of de Pernambuco (Roberto et al. 2017, Santos et al. 2017) were published after (September and December, respectively) the list (May 2017). The snake Xenodon rabdocephalus rabdocephalus was not evaluated by SEMAS, although it had already been registered in Reserva Biológica Pedra Talhada (Roberto et al. 2015) located on the border between the states of Pernambuco and Alagoas. The recent expansion of its distribution to PEC (Andrade Lima et al. 2020) reveals sampling gaps in that
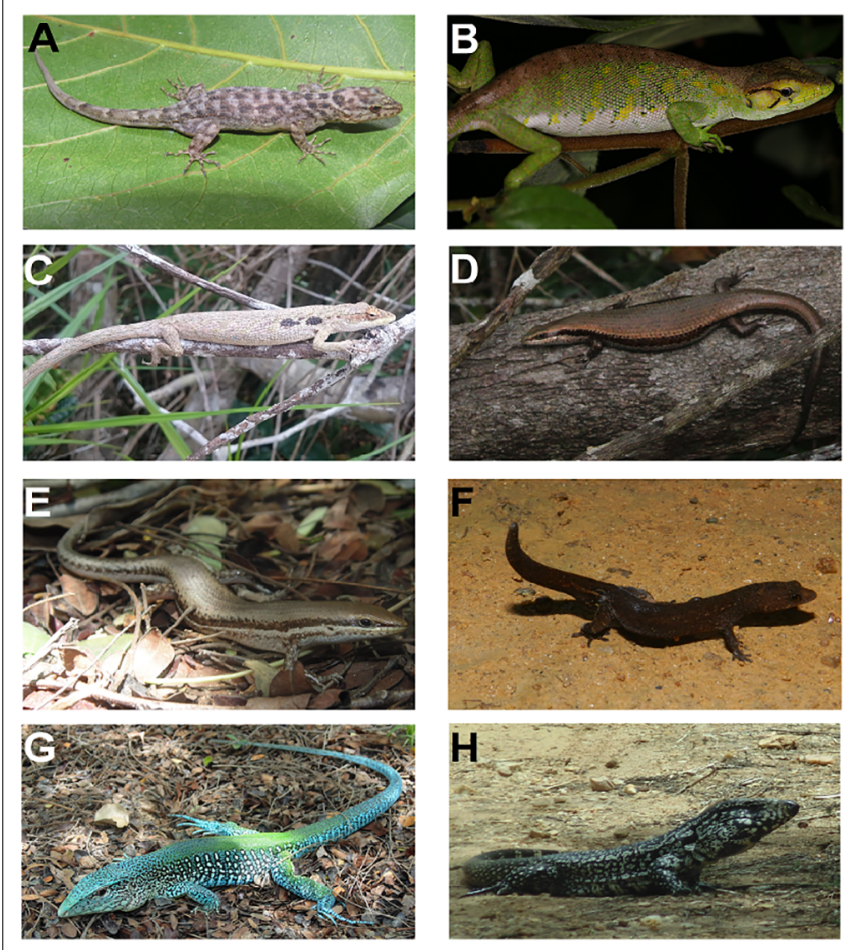

Figure 3. Lizard species registered in Refúgio de Vida Silvestre Matas do Siriji, municipality of São Vicente Férrer, state of Pernambuco, Northeastern Brazil, between April 2018 and September 2019. (A) Gymnodactylus darwinii (LHUFCG 2269), (B) Polychrus marmoratus (unvouchered, male), (C) Polychrus acutirostris (unvouchered), (D) Copeoglossum nigropunctatum (unvouchered), (E) Brasiliscincus heathi (unvouchered), (F) Coleodactylus meridionalis (unvouchered), (G) Ameiva ameiva ameiva (unvouchered, male), (H) Salvator merianae (unvouchered).

region and makes the assessment of its extinction risk more accurate. Therefore, these two species need urgent evaluation by SEMAS. The arboreal lizard Norops ortonii was registered by Oliveira et al. (2016) in the state of Pernambuco prior to the publication of the SEMAS list but was not evaluated.

Although Fernandes et al. (2004), considered that there are no subspecies of Lachesis muta (L. m. muta and L. m. rhombeata), both the IUCN and SEMAS categorized L. m. rhombeata as VU, considering only the populations of the Atlantic Forest distributed from the state of Ceará to the south of the state of Rio de Janeiro (Campbell \& Lamar 2004). Interestingly, this was the second most sighted species of snake within RVS Matas do Siriji, as it was for another location in the state of Pernambuco (Serra do Urubu; Roberto et al. 2017). The main reason for its classification as VU is habitat loss due to intense destruction of the Atlantic Forest (Alves et al. 2014), which is the reality for almost all fragments of the biome in Brazil, but especially those of PEC. Even if they are not considered subspecies, evaluation of the populations of the Atlantic Forest and the Amazon separately by ICMBio would more accurately represent the conservation status of the populations.

The snake Amerotyphlops arenensis, which only occurs in the states of Paraíba, Alagoas and Pernambuco (Graboski et al. 2015, Roberto et al. 2015, 2017), was recently described. This species has not been evaluated by any of the three consulted lists and needs to be urgently. The species was probably not on the SEMAS list because its first record for the state of Pernambuco (Roberto et al. 2017) was published four months after the publication of the list, although there was already a 

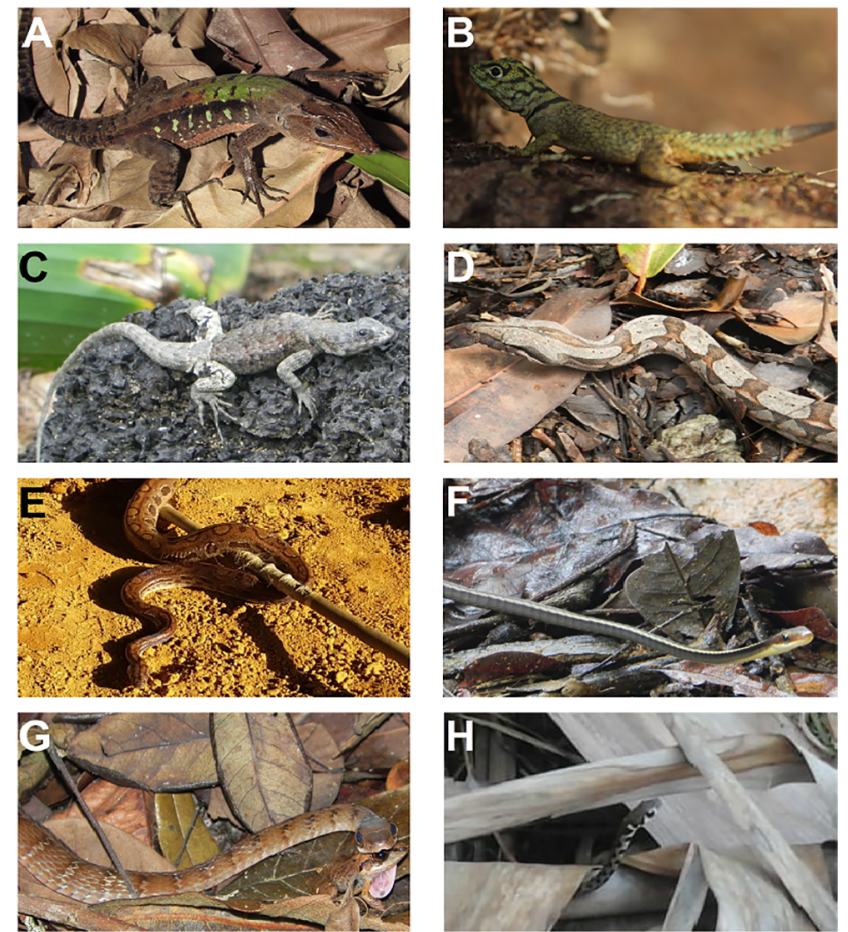

Figure 4. Lizard and snake species registered in Refúgio de Vida Silvestre Matas do Siriji, municipality of São Vicente Férrer, state of Pernambuco, Northeastern Brazil, between April 2018 and September 2019. (A) Kentropyx calcarata (unvouchered), (B) Strobilurus torquatus (unvouchered), (C) Tropidurus hispidus (unvouchered), (D) Boa constrictor (unvouchered), (E) Epicrates assisi (unvouchered), (F) Chironius flavolineatus (unvouchered), (G) Dendrophidion atlantica (unvouchered), (H) Echinanthera cephalomaculata (unvouchered).

record on the border between the states of Pernambuco and Alagoas (Roberto et al. 2015).

It should be noted that the classification of DD (e. g. Dendrophidion atlantica and Micrurus lemniscatus carvalhoi) should not be taken as any less of a concern since little-known species may be at a higher degree of threat than VU or Endangered (EN) species. This is especially true for species with disjunct distributions and low densities and that are restricted to only one region, such as PEC, which, according to Ribeiro et al. (2009), retains about $12.1 \%$ of its original coverage, of which only $1 \%$ is protected.

The clear formation of two groups in the lizard dendrogram (Figure 10A) seems to reflect the phytophysiognomies of the localities: Group I with seasonal (dry) forests west of Planalto da Borborema, which, despite some of them having remnants of Atlantic Forest (montane forests), are inserted in the Caatinga biome and, thus, are strongly influenced by it; and Group II (in which RVS Matas do Siriji is inserted) with predominantly ombrophilous (humid) forests east of Planalto da Borborema, typical of Atlantic Forest, including other montane forests. Some studies involving plants (Santos et al. 2007, Rodal \& Sales 2008, Rodal et al. 2008) and snakes (Pereira-Filho et al. 2020) as models, have demonstrated the division of montane forests into "wet" and "dry", with Planalto da Borborema being indicated as responsible for the division.

We emphasize that the lizard composition of localities was more efficient at showing the formation of these groups of "wet" and "dry" forests than snake composition. This finding probably does not reflect a true random distribution of snakes, but instead the difficulty in their sampling.
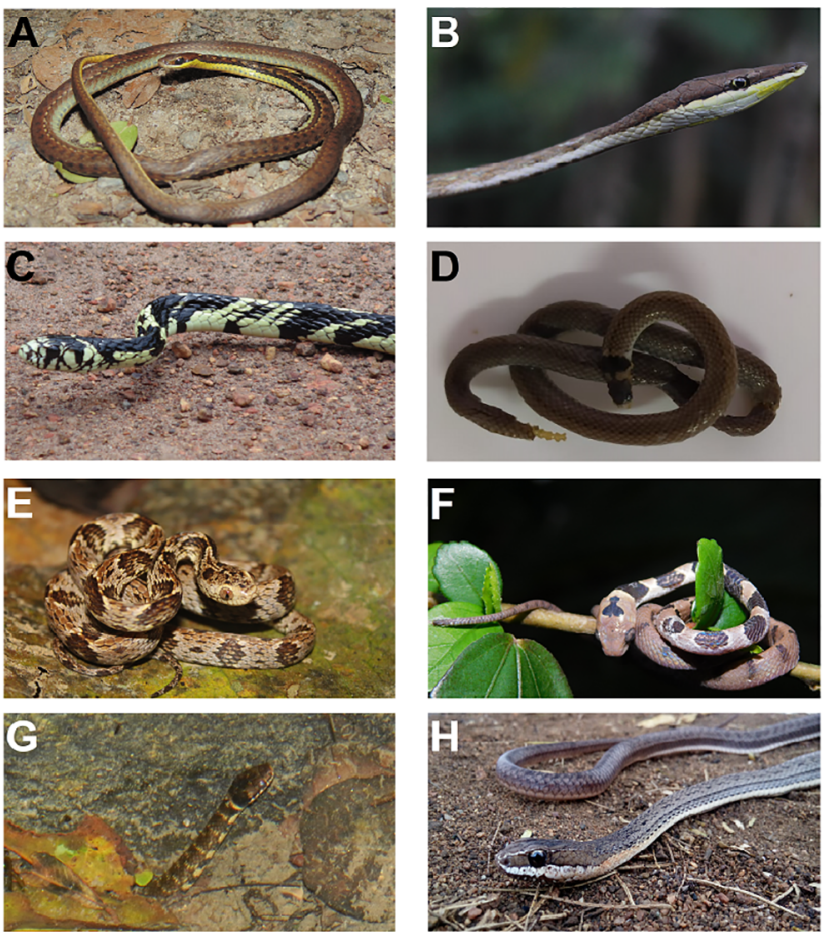

Figure 5. Snake species registered in Refúgio de Vida Silvestre Matas do Siriji, municipality of São Vicente Férrer, state of Pernambuco, Northeastern Brazil, between April 2018 and September 2019. (A) Echinanthera cephalostriata (CPH-UFRPE 5841), (B) Oxybelis aeneus (LHUFCG 2374, juvenile), (C) Spilotes pullatus pullatus (unvouchered), (D) Tantilla melanocephala (LHUFCG 2451), (E) Dipsas variegata (CPH-UFRPE 5273, juvenile), (F) Dipsas sazimai (CPH-UFRPE 5492, juvenile), (G) Erythrolamprus taeniogaster (unvouchered), (H) Philodryas nattereri (unvouchered).

In general, the lizard and snake composition of RVS Matas do Siriji was found to be similar to six other Atlantic Forest fragments of PEC (PEDI-PE, APPMB-PB, RM-AL, RPUPR-AL, MEC-AL and SU-PE), which are all east of Planalto da Borborema and share species frequently recorded in Atlantic Forest environments, such as Dryadosaura nordestina, Dactyloa punctata, Enyalius catenatus, Gymnodactylus darwinii, Norops fuscoauratus, Norops ortonii, Polychrus marmoratus, Strobilurus torquatus, Bothrops leucurus, Dendrophidion atlantica and Lachesis muta. This finding may be a reflection of the proximity of RVS Matas do Siriji to these locations, as well as its phytophysiognomic similarity with the dense ombrophilous forests of these areas. On the other hand, the presence of seasonal montane forest (located in the center and northwest of the Caatinga; west of Planalto da Borborema) (AV-PE, SE-PE, BJ-PE, PEPJ-PB and CA-CE) in the two dendrograms, even while maintaining a lizard fauna more similar to those of the three areas of Caatinga (PNSC-PI, PNSCO-PI and PNCD-BA), demonstrates that the lizard and snake fauna of this type of montane forest (e.g., Gymnodactylus geckoides Spix, 1825, Hemidactylus brasilianus (Amaral, 1935), Lygodactylus klugei (Smith, Martin \& Swain, 1977), Ameivula ocellifera (Spix, 1825), Phyllopezus pollicaris (Spix, 1825), Psychosaura agmosticha (Rodrigues, 2000), Tropidurus semitaeniatus (Spix, 1825), Vanzosaura multiscutata (Amaral, 1933), Apostolepis cearensis Gomes, 1915, Boiruna sertaneja Zaher, 1996, Bothrops erythromelas Amaral, 1923, Epictia borapeliotes (Vanzolini, 1996), Thamnodynastes almae Franco \& Ferreira, 2003 and T. sertanejo Bailey, Thomas \& Silva-Jr, 2005) is strongly influenced by the Caatinga. 

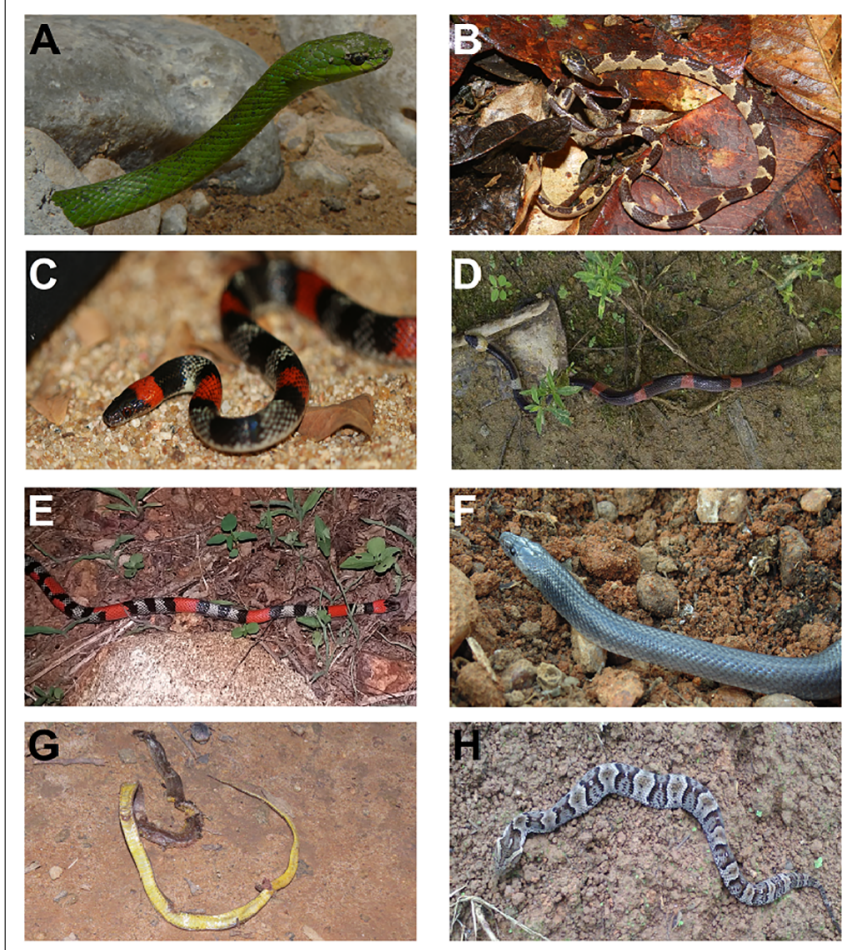

Figure 6. Snake species registered in Refúgio de Vida Silvestre Matas do Siriji, municipality of São Vicente Férrer, state of Pernambuco, Northeastern Brazil, between April 2018 and September 2019. (A) Philodryas olfersii (unvouchered), (B) Imantodes cenchoa (unvouchered), (C) Oxyrhopus guibei (LHUFCG 2286, juvenile), (D) Oxyrhopus petolarius digitalis (unvouchered), (E) Oxyrhopus trigeminus (CPHUFRPE 5275), (F) Pseudoboa nigra (unvouchered), (G) Taeniophallus affinis (LHUFCG 2271), (H) Xenodon rabdocephalus rabdocephalus (unvouchered).
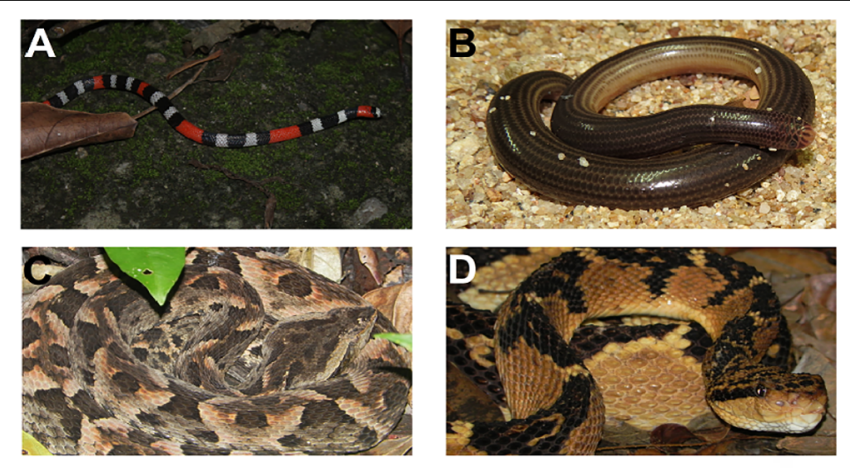

Figure 7. Snake species registered in Refúgio de Vida Silvestre Matas do Siriji, municipality of São Vicente Férrer, state of Pernambuco, Northeastern Brazil, between April 2018 and September 2019. (A) Micrurus lemniscatus carvalhoi (unvouchered), (B) Amerotyphlops arenensis (LHUFCG 2265), (C) Bothrops leucurus (LHUFCG 2368), (D) Lachesis muta (unvouchered).

Although it is part of PEC, some authors (Pôrto et al. 2004, Ferraz \& Rodal 2006, Santos et al. 2007) consider RVS Matas do Siriji to be a "Brejo de Altitude" ("Brejo Nordestino") — another biogeographic subunit of the Atlantic Forest located north of Rio São Francisco being a mosaic of phytophysiognomies with minimal influence from the Caatinga biome on its northwest side and stronger influence by the Atlantic Forest to the south-southeast, including being considered a "área de tensão ecológica" (Caatinga - Atlantic Forest ecotone) (Santos \& Tabarelli 2004). The literature argues that "Brejos de Altitude" are

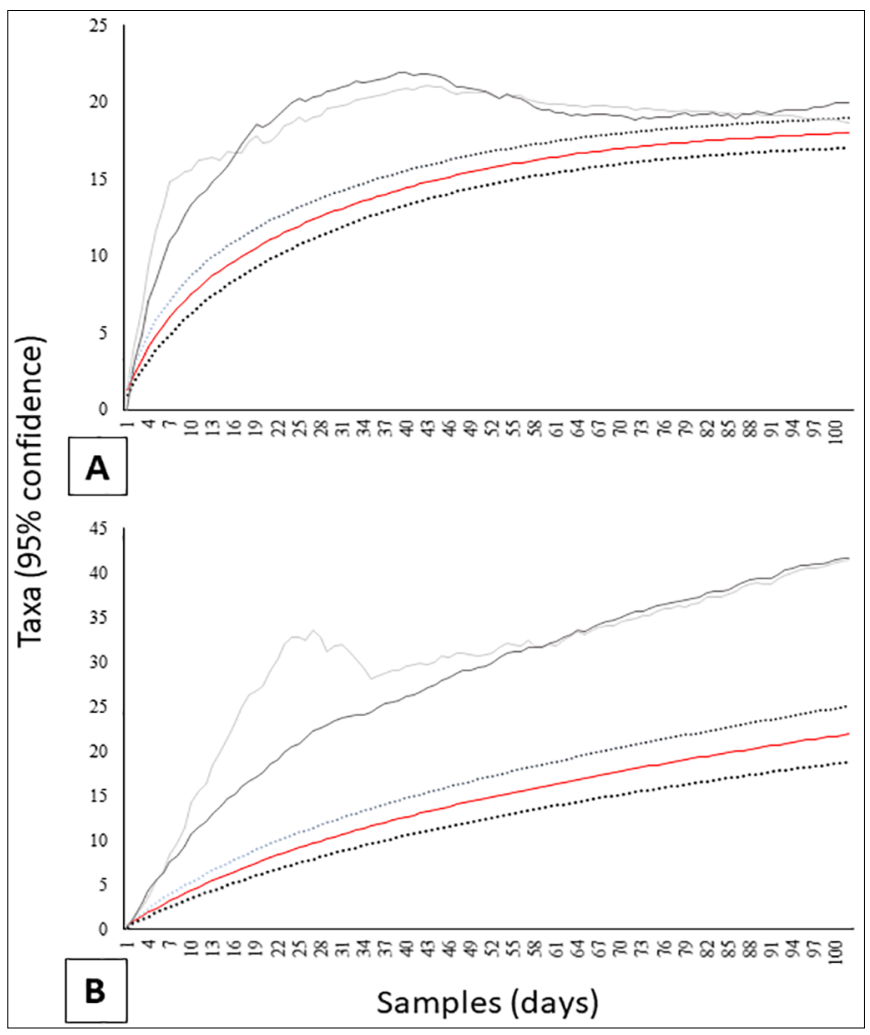

Figure 8. Rarefaction curves (red) with its standart deviation (dashed lines) and ICE (light grey) and Jacknife II (dark grey) curves for lizards (A) and snakes (B) registered in Refúgio de Vida Silvestre Matas do Siriji, municipality of São Vicente Férrer, state of Pernambuco, Northeastern Brazil, between April 2018 and September 2019.

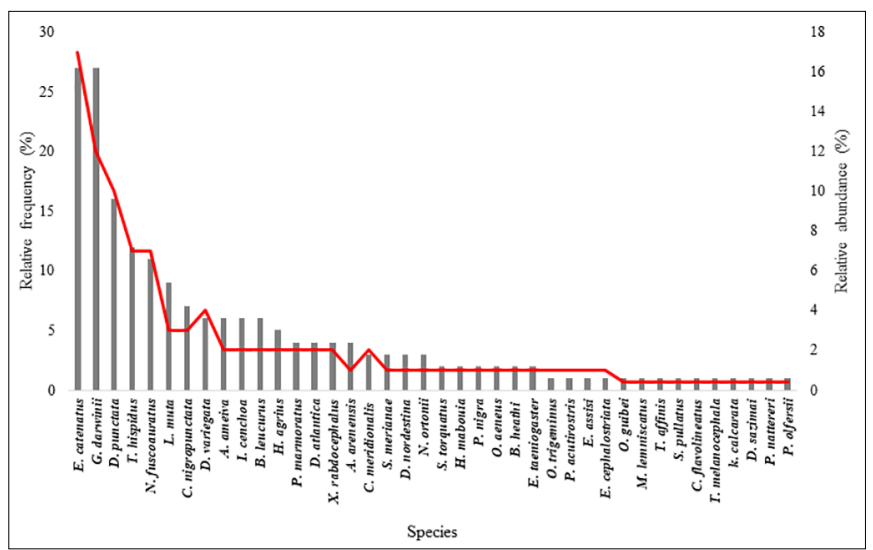

Figure 9. Abundance distribution for species of lizards and snakes registered in Refúgio de Vida Silvestre Matas do Siriji, municipality of São Vicente Ferrer, state of Pernambuco, Northeastern Brazil, between April 2018 and September 2019. Bars $=$ relative frequency, line $=$ relative abundance. The diagram fits the log-normal model $\left(\mathrm{X}^{2}=2.907 ; \mathrm{p}=0.234\right)$.

places where fauna from the Caatinga and Atlantic Forest can coexist (e.g., Borges-Nojosa \& Caramaschi 2003, Pereira-Filho \& Montingelli 2011, Ribeiro et al. 2012, Castro et al. 2019, Freitas et al. 2019). Only four (9.30\%) typical Caatinga species (Brasiliscincus heathi, Hemidactylus agrius, Polychrus acutirostris and Philodryas nattereri) were recorded in RVS Matas do Siriji demonstrating that "Brejos de Altitude" possess different compositions throughout their distribution (e. g. Ribeiro et al. 2012, Roberto et al. 2015, Roberto et al. 2017; Castro et al. 2019, Freitas et al. 2019), with strong or weak influences from the Caatinga. 


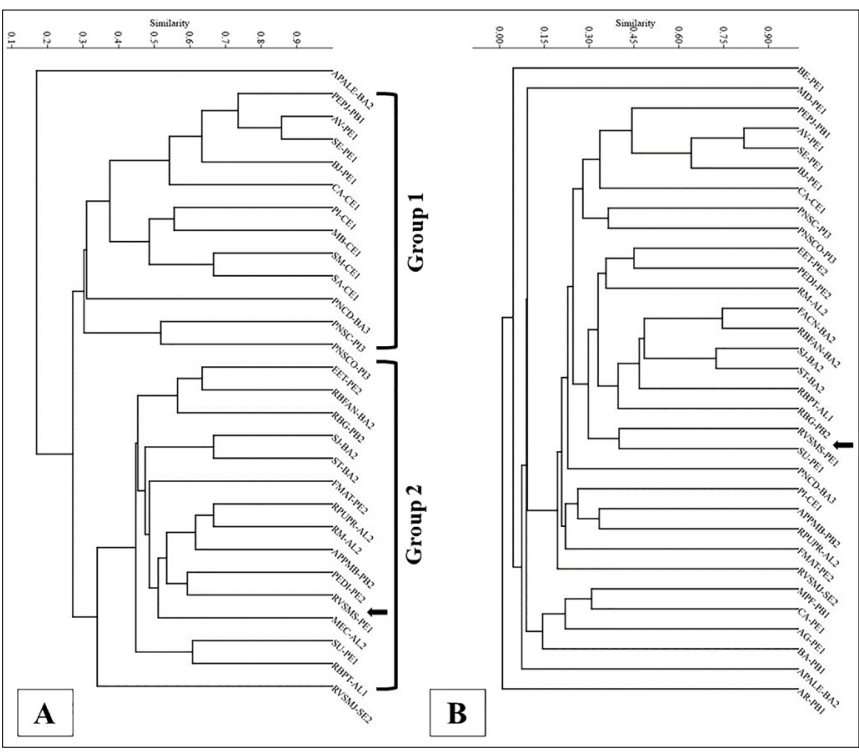

Figure 10. Jaccard similarity dendrograms for lizards (A), involving 29 locations with 12 montane forests (1), 13 low-altitude Atlantic Forest fragments (2) and three areas of mesic caatinga (3); and snakes (B), involving 32 locations with 16 montane forests, 13 low-altitude Atlantic Forest fragments and three areas of mesic caatinga, all in Northeastern Brazil. RVSMS (indicated by the arrow)=Refúgio de Vida Silvestre Matas do Siriji, $\mathrm{SU}=$ Serra do Urubu, $\mathrm{AR}=$ Arcoverde, $\mathrm{BJ}=$ Belo Jardim, $\mathrm{SE}=$ Sertânia, $\mathrm{AG}=$ Agrestina, $\mathrm{BE}=$ Bezerros, $\mathrm{CA}=\mathrm{Cavalos}, \mathrm{MD}=$ Brejo Madre de Deus, EET=Estação Ecológica do Tapacurá, FMAT=Fragmento de Mata Atlântica Tejipió, PEDI=Parque Estadual Dois Irmãos (áreas no Estado de Pernambuco-PE), RBPT $=$ Reserva Biológica Pedra Talhada, $R M=$ Reserva Madeiras, $R P U P R=$ Reserva Particular Usina Porto Rico, MEC=Mata do Engenho Coimbra (áreas no Estado de Alagoas-AL), $\mathrm{AR}=$ Arara, $\mathrm{BA}=$ Bananeira, $\mathrm{MPF}=$ Mata do Pau-Ferro, $\mathrm{PEPJ}=$ Parque Estadual Pico do Jabre, APPMB=Área de Preservação Permanente Mata do Buraquinho, RBG=Reserva Biológica Guaribas (áreas no Estado da Paraíba-PB), $\mathrm{CA}=$ Chapada do Araripe, $\mathrm{PI}=$ Planalto do Ibiapaba, $\mathrm{SM}=$ Serra do Maranguape, $\mathrm{AS}=$ Serra da Aratanha, $\mathrm{MB}=$ Maciço do Baturité, $\mathrm{PNU}=$ Parque Nacional do Ubajara (áreas no Estado do Ceará-CE), RVSMJ=Refúgio de Vida Silvestre Matas do Junco (área no Estado de Sergipe-SE), APALE=Área de Proteção Ambiental Lagoa Encantada, FACN=Floresta Atlântica Costeira a Nordeste, RBFAN=Recôncavo Baiano Floresta Atlântica do Norte, SJ=Serra da Jiboia, ST=Serra do Timbó, PNCD=Parque Nacional Chapada Diamantina (áreas no Estado da Bahia-BA), PNSCO $=$ Parque Nacional Serra das Confusões, $\mathrm{PNSC}=$ Parque Nacional Serra da Capivara (áreas no Estado do Piauí-PI). Grupo 1 = mesic or xeric caatinga; Grupo 2 $=$ Atlantic Forest with dense ombrophilous forest.

Among the species recorded in the present study, $11(25.58 \%)$ are exclusive to the Atlantic Forest, with three (Arenensis arenensis, Dendrophidion atlantica and Echinanthera cephalomaculata) being found only in PEC, confirming the importance of RVS Matas do Siriji for the maintenance of populations of endemic species in this sector of the Atlantic Forest. Another 28 species (65.12\%), including Polychrus marmoratus, Kentropyx calcarata, Dipsas variegata, Oxyrhopus petolarius digitalis, Xenodon rabdocephalus rabdocephalus and Lachesis muta, are shared with the Amazon, as is true for other areas of the PEC (Moura et al. 2012, Roberto et al. 2015, Roberto et al. 2017, Santos et al. 2017, Mesquita et al. 2018), evidencing the meeting of the great Atlantic Forest and Amazon biomes during part of the Cenozoic (Prance 1982, Andrade-Lima 1982, Teixeira et al. 1986, Santos et al. 2007), and demonstrating the irreplaceable role that PEC has played in the reconstruction of the history of these two biomes.

Species distribution patterns and historical relationships between morphoclimatic domains are two major biogeographical enigmas that are frequently investigated in Brazil (Prance 1982, Santos et al. 2007). Accordingly, different groups of animals, such as reptiles, seem to be efficient models for understanding the remote relationships between the Amazon and Atlantic Forest and, more recently, between the Atlantic Forest and the Caatinga in the biogeographic regions of PEC and "Brejos de Altitude" (montane forests) (e. g. Rodrigues et al. 2014; Prates et al. 2018). However, it is known that many areas in these regions have yet to be sampled (BorgesNojosa \& Arzabe 2005, Roberto et al. 2017), making the need to inventory these places urgent, not only for biogeographic reasons but especially for the conservation of existing biodiversity.

In general, the squamate fauna of RVS Matas do Siriji possesses typical elements of the Northeastern Atlantic Forest, with species that only occur in the PEC, and is even similar to Parque Estadual de Dois Irmãos (Santos et al. 2017). Thus, RVS Matas do Siriji reaffirms the capacity of PEC to harbor high endemism of several groups, with Squamata being no exception. Additionally, RVS Matas do Siriji possesses endangered species (Lima et al. 2020) and species with few recent records for Pernambuco (Dias et al. 2019a, 2019b; Freitas et al. 2019b), including five species that are not included in the list of species for the state (SEMAS 2017), highlighting the need to update the list to include such species mainly for the assessment of their conservation status. Although RVS Matas do Siriji has been a full protection Conservation Unit since 2014 and identified as a priority conservation area in PEC for 20 years (MMA 2000), it still suffers from the removal of vegetation, giving way to vast monocultures of sugarcane and bananas. Therefore, RVS Matas do Siriji is home to a rich, threatened and underestimated reptile fauna, and still contributes abundantly to the maintenance of biodiversity, not only of PEC, but the Atlantic Forest as a whole, reasons that call for the protection of this neglected Conservation Unit.

\section{Supplementary Material}

The following online material is available for this article: Appendix

\section{Acknowledgments}

The authors thank the residents of RVS Matas do Siriji for their great support, in particular Maria E. do N. Silva, Edna R. F. da Silva; Juliana D. de Sousa for providing the P. olfersii photo; Paulo Passos for the identification of E. assisi; Erik Wild for translation to English and revision; anonymous referees for the valuable suggestions to this paper; José Ferreira for logistical support; colleagues at Laboratório de Herpetologia of Universidade Federal de Campina Grande (LHUFCG), in particular Mikael Alysson Torres de Oliveira and Wenner Justino Bezerra de Brito, for help in the field, and Ítalo Társis Ferreira de Sousa, for suggestions on the manuscript; Vanessa do N. Brabosa for providing the Micrurus lemniscatus photo; ICMBio for collection licenses $n^{\circ} 11218-1$ and 66285-1; CPRH for collection license, process $n^{\circ}$ 014349/2018; and Coordenação de Aperfeiçoamento de Pessoal de Nível Superior (CAPES) for the scholarship (process number: 88882.461007/201901 ) provided to the senior author for the development of this work.

\section{Author Contributions}

José Henrique de Andrade Lima: data analysis and interpretation, writing the manuscript, and critical review with the addition of intellectual content; data acquisition and the design of the manuscript.

Emerson Gonçalves Dias: data acquisition and the design of the manuscript. 
Rafael Dioni Leandro Costa: data acquisition and the design of the manuscript.

Flávio José Silva: data acquisition and the design of the manuscript.

Erica Suzan Martins Lima: data acquisition and the design of the manuscript.

Ednilza Maranhão dos Santos: data analysis and interpretation, writing the manuscript, and critical review with the addition of intellectual content; data acquisition and the design of the manuscript.

Marcelo Nogueira de Carvalho Kokubum: data analysis and interpretation, writing the manuscript, and critical review with the addition of intellectual content; data acquisition and the design of the manuscript.

\section{Conflicts of Interest}

The authors declare that they have no conflict of interest related to the publication of this manuscript.

\section{References}

ALVES, F.Q., ARGÔLO, A.J.S. \& CARVALHO, G.C. 2014. Reproductive biology of the bushmaster Lachesis muta (Serpentes: Viperidae) in the Brazilian Atlantic Forest. Phyllomedusa 13(2):99-109.

ANDRADE-LIMA, D. 1982. Present day forest refuges in northeastern Brazil. In Biological diversification in the tropics (G.T. Prance, ed). Columbia University Press, New York, p.245-254.

ANDRADE LIMA, J.H., FREITAS, M.A., DUBEUX, M.J.M., NUNES, P.M.S., ROBERTO, I.J. \& KOKUBUM, M.N.C. 2020. New records of Xenodon rabdocephalus (Wied-Neuwied, 1824) (Serpentes: Dipsadidae) in the Pernambuco Endemism Center, Northeastern Brazil. Herpetol. Notes 13:517-522.

ARRUDA, C. 2017. Diversidade de lagartos (Squamata) de uma Floresta Estacional Semidecidual Montana no Sertão da Paraíba. Dissertação Mestrado, Universidade Federal de Campina Grande, Paraíba.

BELTRÃO, B.A., MASCARENHAS, J.C., MIRANDA, J.L.F., JUNIOR, L.C.S., GALVÃO, M.J.T.G. \& PEREIRA, S.N. 2005. Projeto cadastro de fontes de abastecimento por água subterrânea. Diagnóstico do município de São Vicente Férrer, Estado de Pernambuco. CPRM/PRODEEM, Recife.

BORGES-NOJOSA, D.M. 2007. Diversidade de anfíbios e répteis da Serra de Baturité, Ceará. In Diversidade e conservação da biota na Serra de Baturité (T.S. Oliveira \& F.S. Araújo, eds). Edições UFC, Fortaleza, p.225-247.

BORGES-NOJOSA, D.M. \& ARZABE, C. 2005. Diversidade de anfíbios e répteis em áreas prioritárias para a conservação da caatinga. In Análise das variações da biodiversidade do bioma caatinga: suporte a estratégias regionais de conservação (F. S. Araújo, M. J. N. Rodal \& M. R. V. Barbosa, eds.). Ministério do Meio Ambiente, Secretaria de Biodiversidade e Florestas, Brasília, p.227-241.

BORGES-NOJOSA, D.M. \& CARAMASCHI, U. 2003. Composição e análise comparativa da diversidade e das afinidades biogeográficas dos lagartos e anfisbenídeos (Squamata) dos Brejos nordestinos. In Ecologia e conservação da Caatinga (I.R. Leal, J.M.C. Silva \& M. Tabarelli, eds). UFPE, Recife, p.489-540.

BROWN, K.S. JR. 1979. Ecologia, geográfica e evolução nas florestas neotropicais. Tese doutorado, Universidade Estadual de Campinas, São Paulo.

CALDAS, F.L.S., COSTA, T.B., LARANJEIRAS, D.O., MESQUITA, D.O. \& GARDA, A.A. 2016. Herpetofauna of protected areas in the Caatinga V: Seridó Ecological Station (Rio Grande do Norte, Brazil). Check List 12(4):1-14.

CAMPBELL, J.A. \& LAMAR, W.W. 2004. The venomous reptiles of the western hemisphere. V. I, Comstock Publishing Associates, Ithaca, p.1-962.
CARNAVAL, A.C., HICKERSON, M.J., HADDAD, C.F.B., RODRIGUES, M.T. \& MORITZ, C. 2009. Stability predicts genetic diversity in the Brazilian Atlantic Forest hotspot. Science 323:785-789.

CARVALHO, C.M., VILAR, J.C. \& OLIVEIRA, F.F. 2005. Répteis e anfíbios. In Parque Nacional Serra de Itabaiana - Levantamento da biota (C.M. Carvalho \& J.C. Vilar, eds). Aracajú Ibama, p.39-61.

CASTRO, D.P., MÂNGIA, S., MAGALHÃES, F.F.M., RÖHR, D., CAMURUGI, F., SILVEIRA-FILHO, R.R., SILVA, M.M.X., ANDRADE-OLIVEIRA, J.A., SOUSA, T.A., FRANÇA, F.G.R., HARRIS, D.J., GARDA, A.A. \& BORGES-NOJOSA, D.M. 2019. Herpetofauna of protected areas in the Caatinga VI: the Ubajara National Park, Ceará, Brazil. Herpetol. Notes 12:727-742.

CAVALCANTI, L.B.Q., COSTA, T.B., COLLI, G.R., COSTA, G.C., FRANÇA, F.G.R., MESQUITA, D.O.M., PALMEIRA, C.N.S., PELEGRIIN, N., SOARES, A.H.B., TUCKER, D.B. \& GARDA, A.A. 2014. Herpetofauna of protected areas in the Caatinga II: Serra da Capivara National Park, Piauí, Brazil. Check List 10(1):18-27.

CAVALCANTI, D. \& TABARELLI, M. 2004. Distribuição das plantas Amazônico-Nordestinas no Centro de Endemismo Pernambuco: Brejos de Altitude vs. Floresta de Terras Baixas. In Brejos de Altitude em Pernambuco e Paraíba (K.C. Pôrto, J.J.P. Cabral \& M. Tabarelli, eds). MMA, Brasília, Distrito Federal, p.285-296.

CECHIN, S.Z. \& MARTINS, M. 2000. Eficiência de armadilhas de queda (pitfall traps) em amostragens de anfíbios e répteis. Ver. Bras. de Zool. 17:729-740.

COLWELL, R.K. \& CODDINGTON, J.A. 1994. Estimating terrestrial biodiversity through Extrapolation. Phil. Trans. R. Soc. Lond. B. 345(1311):101-118.

COLWELL, R.K. \& ELSENSOHN, J.E. 2014. EstimateS turns 20: Statistical estimation of species richness and shared species from samples, with nonparametric extrapolation. Ecography 37:609-613.

COSTA, G.C., HAMPE, A., LEDRU, M-P., MARTINEZ, P.A., MAZZOCHINI, G.G., SHEPARD, D.B., WERNECK, F.P., MORITZ, C. \& CARNAVAL, A.C. 2017. Biome stability in South America over the last 30 kyr: Inferences from long-term vegetation dynamics and habitat modelling. Global Ecology and Biogeography 00:1-13.

COSTA, H.C. \& BÉRNILS, R.S. 2018. Répteis do Brasil e suas Unidades Federativas: Lista de espécies. Herpetol. Bras. 8(1):11-57.

CRUMP, M.L. \& SCOTT JR., N.J. 1994. Visual encounter surveys. In Measuring and monitoring biological diversity. Standard methods for amphibians (W.R. Heyer, M.A. Donnelly, R.W. Mcdiarmid, L.A.C. Hayek \& M.S. Foster, eds). Smithsonian Institution Press, Washington \& London. p.17-39.

CUNHA, O.R. \& NASCIMENTO, F.P. 1978. Ofídios da Amazônia X - As cobras da região leste do Pará. Publicações Avulsas do Museu Paraense Emílio Goeldi 31, Belém.

DAJOZ, R. 2005. Princípios de Ecologia. 7 ed. Artmed editora, Porto Alegre.

DIAS, E.G., SILVA, F.J., LIMA, E.S.M., SOUZA, J.S. \& SANTOS, E.M. 2019. Echinanthera cephalostriata. Brazil: Pernambuco: São Vicente Férrer. Herpet. Rev. 50(4):748.

DIAS, I.R., MIRA-MENDES, C.V. \& SOLÉ, M. 2014. Rapid inventory of herpetofauna at the APA (Environmental Protection Area) of the Lagoa Encantada and Rio Almada, Southern Bahia, Brazil. Herpetol. Notes 7:627-637.

DI-BERNARDO, M. 1994. Uma nova espécie de Echinanthera Cope, 1894 (Serpentes, Colubridae) do nordeste do Brasil. Biociências 2(2):75-81.

FERNANDES, D.A., FRANCO, F.L. \& FERNANDES, R. 2004. Systematic revision of the genus Lachesis Daudin, 1803 (Serpentes, Viperidae). Herpetologica 60(2):245-260.

FERRAZ, E.M.N. \& RODAL, M.J.N. 2006. Caracterização fisionômicaestrutural de um remanescente de Floresta Ombrófila Montana de Pernambuco, Brasil. Acta Botanica Brasilica 20(4):911-926.

FREITAS, M.A. 2014. Squamate reptiles of the Atlantic Forest of northern Bahia, Brazil. Check List 10(5):1020-1030.

FREITAS, M.A. 2015. Herpetofauna do Nordeste Brasileiro-Guia de Campo. 1 ed. Technical Books, p.1-600. 
FREITAS, M.A., ABEGG, A.D., ARAÚJO, D.S., COELHO, H.E.A., AZEVEDO, E.S., CHAVES, M.F., ROSA, C.M. \& MOURA, G.J.B. 2019a. Herpetofauna of three "Brejos de Altitude" in the interior of the state of Pernambuco, northeastern Brazil. Herpetol. Notes 12:591-602.

FREITAS, M.A., ABEGG, A.D., DIAS, I.R. \& MORAES, E.P.F. 2018. Herpetofauna from Serra da Jibóia, an Atlantic Rainforest remnant in the state of Bahia, northeastern Brazil. Herpetol. Notes 11:59-72.

FREITAS, M.A., BARBOSA, G.G., BERNARDINO, K.P., PINHEIRO-FILHO, J.D. \& ABEGG, A.D. 2019b. First records of the rare snake Echinanthera cephalomaculata Di-Bernardo, 1994 in the state of Pernambuco, Brazil (Serpentes: Dipsadidae). Herpetol. Notes 12:1005-1009.

FREITAS, M.A \& SILVA, T.F.S. 2007. Guia ilustrativo: a herpetofauna das caatingas e áreas de altitudes do nordeste brasileiro. USEB, Pelotas.

FREITAS, M.A., SILVA, T.F.S., FONSECA, P.M., HAMDAN, B., FILADELFO, T. \& ABEGG, A.D. 2019. Herpetofauna of Serra do Timbó, an Atlantic Forest remnant in Bahia State, northeastern Brazil. Herpetol. Notes $12: 245-260$

GONÇALVES, U. S. 2008. Diversidade de espécies e ecologia da comunidade de lagartos de um fragmento de Mata Atlântica no nordeste do Brasil. Dissertação de Mestrado. Universidade Federal do Rio Grande do Norte, Natal.

GOTELLI, N.J. \& COLWELL, R.K. 2001. Quantify in biodiversity: procedures and pitfalls in the measurement and comparison of species richness. Ecol. Lett. 4:379-391.

GRABOSKI, R., PEREIRA-FILHO, G.A., SILVA, A.A.A., PRUDENTE, A.L.C. \& ZAHER, H. 2015. A new species of Amerotyphlops from Northeastern Brazil, with comments on distribution of related species. Zootaxa 3920(3):443-452.

HAMMER, O., HARPER, D.A.T. \& RYAN, P.D. PAST: 2001. Paleontological statistics software package for education and data analysis. Palaeontol. eletronica 4(1):1-9.

HENDERSON, R.W., POWELL, R., MARTÍN, J. \& LOPEZ, P. 2016. Arboreal and fossorial reptiles. In Reptile Ecology and Conservation (C.K. Dodd Jr., ed). Oxford University Press, Oxford.

HOW, R.A. \& SHINE, R. 1999. Ecological traits and conservation biology of five fossorial 'sand-swimming' snake species (Simoselaps: Elapidae) in south-western Australia. J. of Zool. 249:269-82.

ICMBIO - Instituto Chico Mendes de Conservação da Biodiversidade. 2019. Plano de Ação Nacional para Conservação da Herpetofauna Ameaçada da Mata Atlântica Nordestina (PAN) (C.R. Abrahão, G.J.B. Moura, M.A. Freitas \& F. Escarlate-Tavares, eds). Ministério de Meio Ambiente, Instituto Chico Mendes de Conservação da Biodiversidade, Brasília, Distrito Federal.

ICMBIO - Instituto Chico Mendes de Conservação da Biodiversidade. 2018. Livro Vermelho da Fauna Brasileira Ameaçada de Extinção. V. I. 1 Ed. ICMBio, MMA, Distrito Federal.

IUCN - Red List of Threatened Species of the International Union for the Conservation of Nature. 2020. http://www.iucnredlist.org. (Last access in 11/Aug/2019).

LIMA, E.S.M., DIAS, E.G. \& SANTOS, E.M. 2020. Sapos, jias, calangos e serpentes ameaçados de extinção. 1 ed. Editora Universitária da UFRPE, Recife.

LOBO-ARAÚJO, L.W., TOLEDO, M.T.F., EFE, M.A., MALHADO, A.C.M., VITAL, M.V.C., TOLEDO-LIMA, G.S., MACARIO, P., SANTOS, J.G. \& LADLE, R.J. 2013. Bird communities in three forest types in the Pernambuco Centre of Endemism, Alagoas, Brazil. Iheringia 103(2):85-96.

LOEBMANN, D. \& HADDAD, C.F.B. 2010. Amphibians and reptiles from a highly diverse area of the Caatinga domain: composition and conservation implications. Biota Neotrop. 10(3):227-256 http://www.biotaneotropica.org. br/v10n3/en/abstract?article+bn03910032010 (Last access in 02/Feb/2020).

MAGALHÃES, F.M., LARANJEIRAS, D.O., COSTA, T.B., JUNCÁ, F.A., MESQUITA, D.O., RÖHR, D.L., SILVA, W.P., VIEIRA, G.H.C. \& GARDA, A.A. 2015. Herpetofauna of protected areas in the Caatinga IV: Chapada Diamantina National Park, Bahia, Brazil. Herpetol. Notes, 8:243-261.

MAGURRAN, A.E. 1988. Ecological Diversity and its Measurement. Cambridge University Press, London.
MAGURRAN, A. E. 2004. Measuring biological diversity. Wiley-Blackwell Publishing, Victoria.

MARGULES, C.R. \& PRESSEY, R.L. 2000. Systematic conservation planning. Nature 405:243-253.

MARQUES, O.A.V., ETEROVIC, A. \& SAZIMA, I. 2019. Serpentes da Mata Atlântica: guia ilustrado para as florestas costeiras do Brasil. 2 ed. Editora Ponto A, São Paulo.

MARQUES, R., RÖDDER, D., SOLÉ, M. \& TINÔCO, M.S. 2017. Diversity and habitat use of snakes from the coastal Atlantic rainforest in northeastern Bahia, Brazil. Salamandra 53(1):34-43.

MELO, A.S. 2008. O que ganhamos "confundindo" riqueza de espécies e equabilidade em um índice de diversidade? Biota Neotrop. 8(3):21$27 \mathrm{http} / / / \mathrm{www} \cdot$ biotaneotropica.org.br/v8n3/en/abstract?point-ofview+bn00108032008 (Last access in 08/Jan/2020).

MELO, A.S., PEREIRA, R.A.S., SANTOS, A.J., SHEPHERD, G.J., MACHADO, G., MEDEIROS, H.F. \& SAWAYA R.J. 2003. Comparing species richness among assemblages using sample units: Why not use extrapolation methods to standardize different sample sizes? Oikos 101(2):398-410

MELO, I.V., MOURA, G.J.B., FREITAS, M.A., ANDRADE, E.V.E., CASAL, C., ABEGG, A.D. \& KOKUBUM, M.N.C. 2018. New additions to the herpetofauna of the Dois Irmãos State Park, an urban Atlantic Rainforest fragment in northeastern Brazil. Herpetol. Notes, 11:245-254.

MESQUITA, D.O., ALVES, B.C.F., PEDRO, C.K.B., LARANJEIRAS, D.O., CALDAS, F.L.S., PEDROSA, I.M.M.C., RODRIGUES, J.B., DRUMMOND, L.O., CAVALCANTI, L.B.Q., WACHLEVSKI, M., NOGUEIRA-COSTA, P., FRANÇA, R.C. \& FRANÇA, F.G.R. 2018. Herpetofauna in two habitat types (Tabuleiros and Stational Semidecidual Forest) in the Reserva Biológica Guaribas, northeastern Brazil. Herpetol. Notes 11:455-474.

MESQUITA, P.C.M.D., PASSOS, D.C., BORGES-NOJOSA, D.M. \& CECHIN, S.Z. 2013. Ecologia e história natural das serpentes de uma área de Caatinga no Nordeste brasileiro. Pap. Avulsos Zool. 53(8):99-113.

MMA - Ministério do Meio Ambiente. 2000. Avaliação e ações prioritárias para a conservação da biodiversidade da Mata Atlântica e Campos Sulinos. Conservation International do Brasil, Fundação SOS Mata Atlântica e Fundação Biodiversitas.

MORATO, S.A.A., LIMA, A.M.X., STAUT, D.C.P., FARIA, R.G., SOUZAALVES, J.P., GOUVEIA, S.F., SCUPINO, M.R.C., GOMES, R. \& SILVA, M.J. 2011. Amphibians and Reptiles of the Refúgio de Vida Silvestre Mata do Junco, municipality of Capela, state of Sergipe, northeastern Brazil. Check List 7(6):756-762.

MOURA, G.J.B., NOGUEIRA, E.M.Z. \& NETO, E.M.C. 2015. Os anfíbios e répteis da Reserva Madeiras, Estado de Alagoas, Nordeste do Brasil. UEFS Editora, Bahia.

MOURA, G.J.B., SANTOS, E.M., ANDRADE, E.V.E. \& FREIRE, E.M.X. 2011. Distribuição geográfica e caracterização ecológica dos anfíbios de Pernambuco. In Herpetologia no estado de Pernambuco (G.J.B. Moura, E.M. Santos, M.A. Oliveira \& M.C.C. Cabral, eds). IBAMA, Brasília, p.50-84.

MOURA, G.J.B., SANTOS, E.M. \& FREIRE, E.M.X. 2012. Os sauropsidas répteis da Estação Ecológica do Tapacurá. In A Biodiversidade da Estação Ecológica do Tapacurá - uma proposta de manejo e conservação (G.J.B. Moura, S.M. Azevedo Jr \& A.C.A. El-Deir, eds). UFRPE, Recife, p.273-324.

MYERS, N., MITTERMEIER, R.A., MITTERMEIER, C.G., FONSECA, G.A.B. \& KENT, J. 2000. Biodiversity hotspots for conservation priorities. Nature 403:853-858.

OLIVEIRA, C.N., MUNIZ, S.L.S. \& MOURA, G.J.B. 2016. Reptiles of an urban Atlantic Rainforest fragment in the state of Pernambuco, northeastern Brazil. Herpetol. Notes 9:175-183.

PEDROSA, I.M.M.C., COSTA, T.B., FARIA, R.G., FRANÇA, F.G.R., LARANJEIRAS, D.O., OLIVEIRA, T.C.S.P., PALMEIRA, C.N.S., TORQUATO, S., MOTT, T., VIEIRA, G.H.C. \& GARDA, A.A. 2014. Herpetofauna of protected areas in the Caatinga III: The Catimbau National Park, Pernambuco, Brazil. Biota Neotrop. 14(4):1-12 http://dx.doi. org/10.1590/1676-06032014004614 (Last access in 02/Jan/2020). 
PEREIRA-FILHO, G.A. \& MONTINGELLI, G.G. 2011. Check list of snakes from the Brejos de Altitude of Paraíba and Pernambuco, Brazil. Biota Neotrop. 11(3):145-151 http://www.biotaneotropica.org.br/v11n3/en/ abstract?article+bn02211032011 (Last access in 02/Jan/2020).

PEREIRA-FILHO, G.A., FREITAS, M.A., VIEIRA, W.L.S., MOURA, G.J.B. \& FRANÇA, F.G.R. 2020. State of knowledge and conservation of the snakefauna of the "Brejos de Altitude" in the Pernambuco Endemism Center, Northeastern Brazil. Ethnobiol. Conserv. 9(12):1-15.

PIETROBOM, M.R. \& BARROS, I.C.L. 2002. Pteridófitas de um remanescente de floresta atlântica em São Vicente Férrer, Pernambuco, Brasil: Pteridaceae. Acta Bot. Bras. 16(4):457-479.

PÔRTO, K.C., CABRAL, J.J.P. \& TABARELLI, M. 2004. Brejos de Altitude em Pernambuco e Paraíba: história natural, ecologia e conservação. MMA, Brasília, Distrito Federal.

PORTO, T.J., CARNAVAL, A.C. \& ROCHA, P.L.B. 2013. Evaluating forest refugial models using species distribution models, model filling and inclusion: a case study with 14 Brazilian species. Diversity and Distributions 19:330-340.

PRANCE, G.T. 1982. Forest refuges: evidences from woody angiosperms. In Biological diversification in the tropics (G.T. Prance, ed). Columbia University Press, New York, p.137-158.

PRATES, I., MELO-SAMPAIO, P. R., QUEIROZ, K., CARNAVAL, A. C., RODRIGUES, M.T. \& DRUMMOND, L. O. 2018. Discovery of a new species of Anolis lizards from Brazil and its implications for the historical biogeography of montane Atlantic Forest endemics. Amphib-reptil. 41:1-17.

QUEISSADA, I.C.S.T. 2009. Diversidade da herpetofauna de uma área de Mata Atlântica do Estado de Alagoas: a Reserva Particular da Usina Porto Rico, Campo Alegre. Dissertação Mestrado, Universidade Estadual Paulista “Júlio de Mesquita Filho", São Paulo.

QUINTELA, F.M., PINHEIRO, R.F. \& LOEBMAN, D. 2010. Composição e uso do habitat pela herpetofauna em uma área de mata paludosa da Planície Costeira do Rio Grande do Sul, extremo sul do Brasil. Rev. Bras. Biociênc. 9(1):6-11.

RIBEIRO, M.C., METZGER, J.P., MARTENSEN, A.C., PONZONI, F.J. \& HIROTA, M.M. 2009. The Brazilian Atlantic forest: How much is left, and how is the remaining forest distributed? Implications for conservation. Biol. Conserv. 142(6):1141-1153.

RIBEIRO, S.C., ROBERTO, I.J., SALES, D.L., ÁVILA, R.W. \& ALMEIDA, W.O.A. 2012. Amphibians and reptiles from the Araripe bioregion, northeastern Brazil. Salamandra 48(3):133-146.

RIBEIRO, S.C., FERREIRA, F.S., BRITO, S.V., SANTANA, G.G., VIEIRA, W.L.S., AVES, R.R.N. \& ALMEIDA, W.O.A. 2008. The squamata fauna of the Chapada do Araripe, Northeastern Brazil. Cad. Cul. Ciên. 1(1):67-76.

RIZZINI, C.T. 1997. Tratado de fitogeografia do Brasil. Âmbito Cultural Edições Ltda, Rio de Janeiro.

ROBERTO, I.J., ÁVILA, R.W. \& MELGAREJO, A.R. 2015. Répteis (Testudines, Squamata, Crocodylia) da Reserva Biológica de Pedra Talhada. In Biodiversidade da Reserva Biológica de Pedra Talhada (Alagoas, Pernambuco - Brasil) (A. Studer, L. Nusbaumer, R. Spichiger, eds). Boissiera 68:357-375.

ROBERTO, I.J., OLIVEIRA, C.R., ARAUJO-FILHO, J.A., OLIVEIRA, H.F. \& ÁVILA, R.W. 2017. The herpetofauna of the Serra do Urubu mountain range: a key biodiversity area for conservation in the brazilian Atlantic Forest. Pap. Avulsos Zool. 57(277):347-373.

RODAL, M.J.N., BARBOSA, M.R.V. \& THOMAS, W.W. 2008. Do the seasonal forests in northeastern Brazil represent a single floristic unit? Braz. J. Biol. 68:467-475.

RODAL, M.J.N. \& SALES, M.F. 2008. Panorama of the montane forests. Mem. N. Y. Bot. Gard. 100:535-553.

RODAL, M.J.N., SALES, M.F. \& MAYO, S.J. 1998. Florestas Serranas de Pernambuco. Localização e Conservação do Remanescentes dos Brejos de Altitude. UFRPE, Imprensa Universitária, Recife.
RODRIGUES, M.T., BERTOLOTTO, C.E.V., AMARO, R.C., YONENAGAYASSUDA, Y., FREIRE, E.M.X. \& PELLEGRINO, K.C.M. 2014. Molecular phylogeny, species limits, and biogeography of the Brazilian4endemic lizard genus Enyalius (Squamata: Leiosauridae): An example5of the historical relationship between Atlantic Forests and Amazonia. Mol. Phylogenet. Evol. 81:137-146.

SANTANA, G.G., VIEIRA, W.L.S., PEREIRA-FILHO, G.A., DELFIM, F.R., LIMA, Y.C.C. \& VIEIRA K.S. 2008. Herpetofauna em um fragmento de Floresta Atlântica no Estado da Paraíba, Região Nordeste do Brasil. Biotemas 21(1):75-84.

SANTOS, A.M.M., CAVALCANTI, D.R., SILVA, J.M.C. \& TABARELLI, M. 2007. Biogeographical relationships among tropical forests in north-eastern Brazil. J. Biogeogr. 34:437-446.

SANTOS, A.M.M. \& TABARELLI, M. 2004. Integridade, esforço e diretrizes para conservação dos Brejos de Altitude da Paraíba e Pernambuco. In Brejos de Altitude em Pernambuco e Paraíba, História Natural, Ecologia e Conservação (K.C. Porto, J.J.P. Cabral \& M. Tabarelli, eds). MMA. Série Biodiversidade, Brasília, Distrito Federal, p.309-318.

SANTOS, E.M., CORREIA, J.M.S. \& BARBOSA, V.N. 2017. Guia de Répteis do Parque Estadual de Dois Irmãos. 1 ed. Editora Universitária da UFRPE, Recife

SEMAS - SECRETARIA DE MEIO AMBIENTE E SUSTENTABILIDADE. 2017. Lista estadual oficial de espécies da fauna ameaçadas de extinção Répteis. Resolução SEMAS n¹ de 15 de maio de 2017. Diário Oficial do Estado de Pernambuco. Recife.

SILVA, J.M.A \& CASTELETI, C.H.M. 2005. Estado da biodiversidade da Mata Atlântica brasileira. In Mata Atlântica Biodiversidade, Ameaças e Perspectivas (C. Galdino-Leal \& I.G. Câmara, eds). Fundação SOS Mata Atlântica, São Paulo, Conservação Internacional, Belo Horizonte.

SILVA, J.M.C., SOUZA, M.C. \& CASTELETTI, C.H.M. 2004. Areas of endemism for passerine birds in the Atlantic forest, South America. Global Ecol. Biogeogr. 13:85-92.

SILVA, S.T., SILVA, U.G., SENA, G.A.B. \& NASCIMENTO, F.A.C. 2006. A biodiversidade da Mata Atlântica alagoana: anfíbios e répteis. In: A Mata Atlântica em Alagoas (F.B.P.M. Moura, ed). EDUFAL, Maceió, p.65-76.

SOS MATA ATLÂNTICA \& INPE. 2019. Atlas dos remanescentes florestais da Mata Atlântica. Período 2017-2018. Fundação SOS Mata Atlântica, São Paulo.

TEIXEIRA, D.M., NACINOVIC, J.B. \& TAVARES, M.S. 1986. Notes on some birds of northeastern Brazil. Bull. Br. Ornithol. Club 106:70-74.

TYLER, H., BROWN, K.S. JR \& WILSON, K. 1994. Swallowtail butterflies of the Americas. Study in biological dynamics, ecological diversity, biosystematics and conservation. Scientific Publishers, Gainesville, Florida.

TOZETTI, A.M., SAWAYA, R.J., MOLINA, F.B., BÉRNILS, R.S., BARBO, F.E., LEITE, J.C.M., BORGES-MARTINS, M., RECODER, R., JUNIOR, M.T., ARGÔLO, A.J.S., MORATO, S.A.A. \& RODRIGUES, M.T. 2017. Répteis. In Revisões em Zoologia: Mata Atlântica (E.L.A. Monteiro-Filho \& C.E. Conte, eds). UFPR, Curitiba, p.315-364.

VALE, M.M., TOURINHO. L., LORINI, M.L., RAJÃO, H. \& FIGUEIREDO, M.S.L. 2018. Endemic birds of the Atlantic Forest: traits, conservation status, and patterns of biodiversity. J. Field Ornithol. 89(3):193-206.

VECHIO, F.D., TEIXEIRA JR, M., RECODER, R.S., RODRIGUES, M.T. \& ZAHER, H. 2016. The herpetofauna of Parque Nacional da Serra das Confusões, state of Piauí, Brazil, with a regional species list from an ecotonal area of Cerrado and Caatinga. Biota Neotrop. 16(3):1-19 http:// dx.doi.org/10.1590/1676-0611-BN-2015-0105 (Last access in 15/Dec/2019).

Received: $13 / 08 / 2020$

Revised: 25/01/2021

Accepted: 21/02/2021

Published online: 24/03/2021 